\title{
Aging versus youth: Endocrine aspects of vulnerability for COVID-19
}

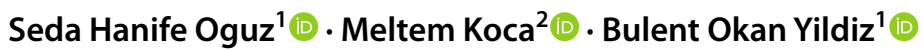 \\ Accepted: 13 April 2021 / Published online: 16 April 2021 \\ (c) The Author(s), under exclusive licence to Springer Science+Business Media, LLC, part of Springer Nature 2021
}

\begin{abstract}
Coronavirus Disease 2019 (COVID-19) is characterized with a wide range of clinical presentations from asymptomatic to severe disease. In patients with severe disease, the main causes of mortality have been acute respiratory distress syndrome, cytokine storm and thrombotic events. Although all factors that may be associated with disease severity are not yet clear, older age remains a leading risk factor. While age-related immune changes may be at the bottom of severe course of COVID-19, age-related hormonal changes have considerable importance due to their interactions with these immune alterations, and also with endothelial dysfunction and comorbid cardiometabolic disorders. This review aims to provide the current scientific evidence on the pathogenetic mechanisms underlying the pathway to severe COVID-19, from a collaborative perspective of age-related immune and hormonal changes together, in accordance with the clinical knowledge acquired thus far.
\end{abstract}

Keywords COVID-19 $\cdot$ SARS-CoV-2 $\cdot$ Aging, biological $\cdot$ Senescence $\cdot$ Immunity $\cdot$ Endocrine System

\section{Introduction}

Severe Acute Respiratory Syndrome Coronavirus-2 (SARSCoV-2), the cause of Coronavirus Disease 2019 (COVID-19), is an enveloped RNA Beta Coronavirus that emerged in Wuhan, China, in December of 2019 [1]. To date, more than 130 million people were infected and over 2.8 million COVID-19-related deaths were recorded by The World Health Organization [2].

SARS-CoV-2 infects humans with its viral S protein binding to cellular Angiotensin-converting enzyme 2 (ACE2) [3]. ACE2 expression has been identified in a variety of human tissues [4], which may explain the diversity of clinical presentation. COVID-19 is characterized with a wide range of clinical symptoms, from asymptomatic disease to acute respiratory distress syndrome (ARDS) and cytokine storm, and may result in mortality due to respiratory insufficiency, multiorgan failure (MOF) or thrombotic events [5]. Overactivation of classical pathway by the downregulation of ACE2 along

Bulent Okan Yildiz

yildizbo@yahoo.com

1 Division of Endocrinology and Metabolism, Department of Internal Medicine, Hacettepe University School of Medicine, Ankara, Turkey

2 Division of Geriatrics, Department of Internal Medicine, Hacettepe University School of Medicine, Ankara, Turkey with dysregulated and excess activation of the immune system resulting in cytokine storm have been identified as the main pathways leading to severe COVID-19 [6, 7]. Older adults, male gender, and patients with certain comorbidities have been under the risk of severe disease $[8,9]$.

Severe course of COVID-19 in older adults was formerly addressed by epidemiological and observational studies $[5,8$, 10-12]. Consequences of biological aging including age-related alterations in the immune and endocrine systems, and increasing incidence of chronic diseases leave older adults vulnerable to infections such as COVID-19. This review aims to approach to the vulnerability of the adult population to severe COVID-19 with a unifying perspective by addressing age-related hormonal and immune alterations together (Fig. 1).

\section{Altered immunity in older adults and COVID-19}

Biological aging is an inevitable process which causes functional decline in affected cell-tissue-organ-system chain of the living organism. Together with the cellular aging, unfavorable aging-related immune system changes, termed as "immunosenescence" seems to be at the bottom of various age-related chronic diseases and the vulnerability to acute clinical conditions, particularly infections. On the other side, this remodeling occurs due to the struggle 


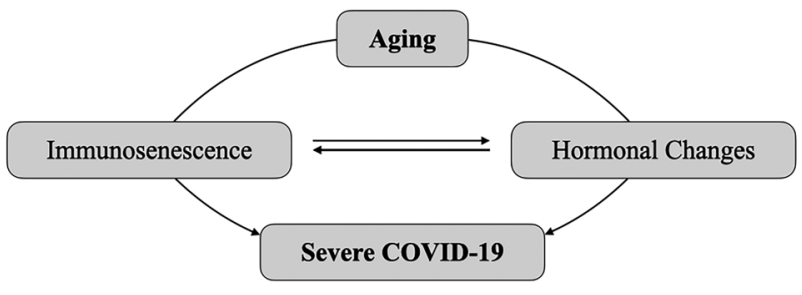

Fig. 1 The interrelation of age-related hormonal and immune alterations in severe COVID-19. Biological aging and interconnected agerelated alterations in the immune and endocrine systems leave older adults vulnerable to infections such as COVID-19. COVID-19: Coronavirus disease 2019

of the organism to maintain the homeostasis and adaptation to environmental stressors [13]. It is shaped under interactions of multiple intrinsic factors including genetics, sex hormones, insulin resistance, and adiposity [14] and various acute and chronic extrinsic or intrinsic factors might accelerate or decelerate its progression [15]. Therefore, phenotype and pace of both immunosenescence and cellular senescence progression is not uniform and might differ between individuals regardless of chronologic age. Hence, it would be a rather superficial approach to only focus on the statistics from the clinical data observed in certain age groups by ignoring the heterogeneity of clinical characteristics of the older patients. We believe that this subject should be examined in terms of the agingrelated decrease in function at the level of organ, tissue or even cell, which is individualized by the genetic background, neuroendocrine factors which too are subject to alter with aging, and other risk factors for each patient.

\subsection{Cellular senescence}

Cellular senescence describes a state that cell enters due to a current stressful condition and the first identified of these stress situations is telomere shortening [16]. It is characterized with permanent cell cycle arrest, and hypersecretion of various proinflammatory mediators to trigger the immune system to eradicate this stressor [17]. However, the word 'senescence' here may sound misleading as if it refers to diminishing functions of an aging cell near to death. Contrarily, senescent cells are actively secreting and highly viable. In fact, it is not the cellular senescence itself, but the accumulation of chronic senescent cells induced by persistent and cumulative damage, leads to the decrease in tissue function and their secretome contribute to the mild chronic inflammation of aging, referred as 'inflammaging' [15]. While the molecules produced by senescent cells, altogether termed as senescence-associated secretory phenotype (SASP), might vary from cell to cell, their common feature is that they are pro-inflammatory in nature [14], and work as an 'inflammatory-call' to immune system in case of any stress exposure, including infection. In the aging process, SASP creates its self-feeding cycle by triggering senescence in both normal and progenitor cells of functioning tissues via paracrine activity [15].

Older age, male sex and multimorbidity are the most important risk factors for severe COVID-19 [5]. Even at first glance it seems obvious that these are the very same factors that increase cellular senescence and immunosenescence. Furthermore, there are some more important clues that support this suspicion. Telomere length (TL), particularly that of lymphocytes is known to be a critical marker of biological aging. Such that, lymphocytes with shorter TL are among the drawbacks of aging immune system which significantly contributes vulnerability to certain infections due to their decreased reconstitutive capacity. In line with that, regardless of age, shorter TL has been found to be associated with both severe COVID-19 [18, 19], and its risk factors: increasing age, aging-related diseases, and male sex [20]. The senescence of epithelial and stromal cellular components of the lungs probably facilitates replication of SARS-CoV-2 already, as locally increased interleukin (IL)-6 recruits myeloid-derived suppressor cells and establishes an immunosuppressed microenvironment [21, 22]. The diminished regeneration-competence of senescent type-II alveolar cells and T\&B lymphocytes with shorter TLs seem to be explanatory to severe-COVID-19-related lung tissue damage and lymphopenia, respectively [18-20]. Additionally, certain SASP components like nuclear factor-kappa B (NF-kB) downstream cytokines and type-I interferons (IFNs) contribute cellular senescence by inducing telomere attrition [23] which in turn sustains this vicious senescence cycle. On the other hand, severe COVID-19 is driven by suppressed IFN-I response whose inducibility is already found to be decreased in aging to balance its cellular senescence triggering effect [24]. In other words, the blunted IFN-I response seems to be an adaptive mechanism to keep the pace of the cellular senescence under control in expense of an increased vulnerability to SARS-CoV-2 infection.

Aside from the important influence of well-known factors such as genetics, hormonal changes, and cumulative stress of aging, cellular senescence -regardless of the age- could be accelerated or even initiated by certain aging-related chronic diseases and major stressors including acute diseases like viral infections [15]. According to the current evidence, triggering a senescence chain by either directly infecting cells or indirectly via paracrine effect of the released proinflammatory cytokines seems like an important sword of SARSCoV-2 [25].

Cytokine storm is the characteristic feature of the clinical deterioration in COVID-19 and it is the uncontrolled production of proinflammatory cytokines whose baseline secretion is already increased in the context of inflammaging [14]. 
Mitochondrial dysfunction which could briefly be described as disrupted homeostasis of mitochondria in favor of fusion and elongation, and iron dysregulation which further aggravates oxidative stress produced by aging-mitochondria are also among the overlapping mechanisms for cellular senescence and severe COVID-19 [26, 27].

\subsection{Immunosenescence}

Immunosenescence is the term that describes age-related malfunctioning of both innate and adaptive immunity and dysregulation of their interactions. It is well-known that immunosenescence is mainly responsible from increased vulnerability to severely progressive acute infections like pneumonia or sepsis [28]. Also, we have plenty of knowledge about how each immune cell type is affected in terms of function and proportion, however there are still lots of gaps to fill for thoroughly understanding immunosenescence and the mechanisms that lead to it.

Immunosenescence is characterized by impaired recognition and antigen presentation of pathogens by innate immunity, reduced ability to generate specific immune responses due to polarization of lymphocytes from naïve to memory cells despite increased basal pro-inflammatory tone: inflammaging [29]. Broadly, it is not simply the loss of function of the immune system rather its dysregulated or improper response to infectious agents and autoinflammatory/hyperinflammatory reactions that is prone to failure in terms of clinical outcomes and effectivity of vaccines [28, 30]. Being unable to develop an effective specific response, the main handicap of immunosenescence seems to be impairment in coping with novel pathogens like SARS-CoV-2 [31].

\subsubsection{PRRs, IFN-I, antigen presenting cells}

Recognition of pathogen and damage associated molecular patterns is the initiating step for the immune response against SARS-CoV-2. As an RNA virus, SARS-CoV-2 is mainly sensed by transmembrane toll-like receptors (TLRs) 3,7,8 and cytosolic RIG-1-like receptor (RLR). Almost all types of pattern recognition receptors (PRRs) were found to be lower in antigen presenting cells (APCs) of older adults $[24,31]$ and demonstrated lower cytokine production upon stimulation [24, 31, 32] (Fig. 2). This impaired effectivity of PRRs blunts the downstream steps to produce type-I IFNs and NF- $\kappa B$ centered cytokine response. Type-I IFNs (IFN- $\alpha$ and $-\beta$ ) are the molecules of utmost importance for antiviral response in SARS-CoV-2 [33]. Type-I IFNs generate expression of various IFN-inducible genes which provides the phenotype change of the target cell in a way that prevents viral replication and metabolism, besides trigger $\mathrm{T}$-cell activation for the virus-specific immune response [34]. Based on the knowledge that earlier SARS-CoV infection, the causative agent of SARS, induces downregulation of Type-I IFNs that resulted in an impaired innate immune response [35, 36], a similar strategy was also described for SARS-CoV-2 $[33,37]$ (Fig. 2). Additionally, Hadjadj reported that unlike mild and moderate groups, in severe and critical COVID19 patients, global IFN-I response was significantly downregulated, which seemed to be climacteric as it preceded clinical deterioration to respiratory failure [38]. Antiviral IFN- $\alpha$ response was already shown to be delayed [32] and the dynamism of the induced IFN responses is impaired with aging independent from PRR signaling [24, 39]. Correspondingly, the course of IFN- $\alpha$ response was low or even absent in critical COVID-19 patients, high but short-lived in severe patients, whereas sustainably powerful in mild and moderate cases [38]. An insufficient initial IFN-I response is critical for later course of infection, as it results in uncontrolled viral replication. The higher viral loads in the plasma samples of severe and critically ill COVID-19 patients [38] and in oropharyngeal saliva samples of older patients [40] are likely to reflect such a lack of control on viral replication. Likewise, higher titers of viral shedding which were significantly more common in males and older patients were related to more rapid course of SARS and higher mortality rates [41]. These results also might be explained with the failure of early innate immune response by IFN-I which is brought by immunosenescence.

Dendritic cells (DCs) are the cellular source of PRRs and type-I IFNs. Plasmacytoid DCs (pDC) are particularly essential in development of primary nonspecific antiviral responses via viral recognition, and restriction of viral replication by inducing cytotoxic and T-helper (Th) cells with both antigen presentation and IFN-gamma secretion [42]. Number of pDCs were found to be selectively decreased in senescence process [43] (Fig. 2).

\subsubsection{Macrophages and monocytes}

Macrophages with their balancing and orchestrating properties are the central cells of the immune system. Their substantial functional alteration with aging which is termed as "macrophaging" has a hand in inflammaging and is largely responsible for impaired immune responses [44]. Macrophaging is characterized with weakened antigen presentation and impaired migration, phagocytosis, and production of certain chemotactic factors [45]. Macrophages bear different phenotypic features and functional properties that are shaped under the effect of multiple signals received from the microenvironment in which they are located [46]. The oxidative burden of aging and the management of its cumulative stress mainly via stress hormones and other neuroendocrine factors, appear to be the pivotal determinants of the changes in tissue architecture and signaling pathways [14, 47]. 


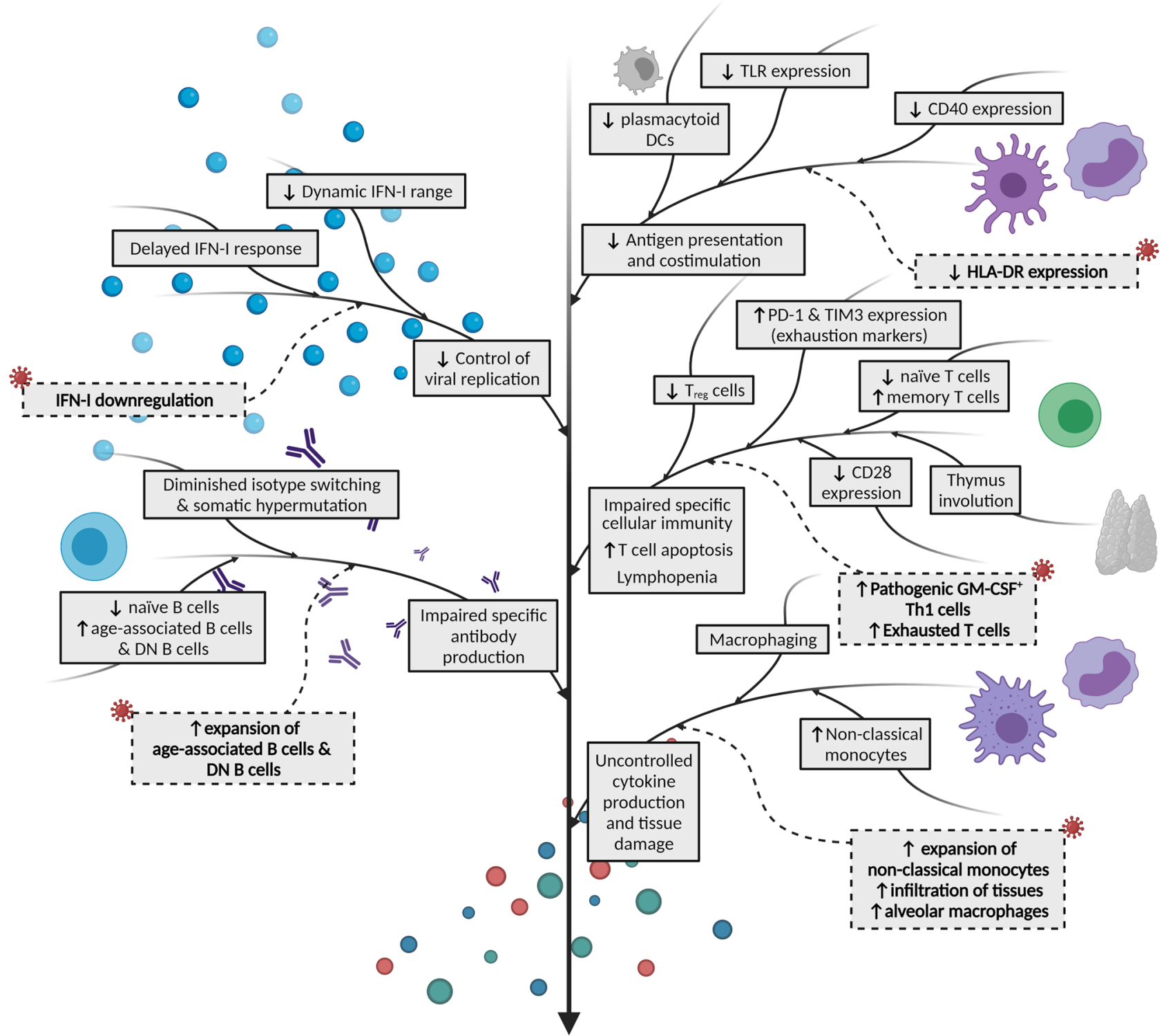

Severe COVID-19

Fig. 2 Immunosenescence mechanisms paving the way for severe COVID-19. Immunosenescence is the gradual unfavorable alterations in innate and adaptive immune mechanisms with aging. Diminished pathogen recognition, attenuated virus-induced IFN-I respose and dysfunctional macrophages/monocytes are the drawbacks of innate immunity that fail to provide the first line of defense to control viral replication. Impaired antigen presentation and costimulation further complicate generation of effective cellular and humoral immune

Another proposed theory is that macrophages, particularly alveolar macrophages being an expressor of ACE2 and transmembrane protease/serine subfamily 2 (TMPRSS2), may act as a reservoir facilitating the invasion of SARS-CoV-2 in the lungs, and its migration to other tissues, although it is not clear whether they allow viral replication. The increase in the number of alveolar macrophages and their dysfunctional responses by aging T\&B cell populations. Dashed lines indicate the probable contributions of SARS-CoV-2 infection to these age-related immunological alterations. CD: cluster of differentiation; DC: dendritic cell; DN: double negative; GM-CSF: granulocyte-macrophage colony-stimulating factor; HLA-DR: human leukocyte antigen - DR isotype; IFN-I: type-I interferon; PD-1: Programmed Death 1; Th: helper T; TIM-3: T cell immunoglobulin mucin domain-3; TLR: tolllike receptor; Treg: regulatory $\mathrm{T}$

alterations in aging-related diseases which have a chronic inflammatory pathogenesis such as diabetes and heart failure, and the more severe course of COVID-19 in these patient groups might be clues supporting this theory [48].

Monocytes are the circulating pool of tissue-resident APCs and are among the main contributors to the systemic inflammatory milieu determined by serum cytokine levels. 
Older individuals had lower expression of co-stimulatory CD40 molecule on their monocytes which impairs their trigger mission to proceed T- and B-cell responses [32]. Monocytes, grouped as classical $\left(\mathrm{CD} 14^{++} \mathrm{CD} 16^{-}\right)$, intermediate or transitional $\left(\mathrm{CD} 14^{++} \mathrm{CD} 16^{+}\right)$, and non-classical $\left(\mathrm{CD} 14^{+} \mathrm{CD} 16^{++}\right)$subtypes, have different certain properties in terms of their maturity and immune response behaviors [49]. The percentage of non-classical (inflammatory) monocytes increase with aging [50] and they are known to be the group of monocytes that demonstrate cellular senescencelike properties [51]. The proportion of intermediate and nonclassical monocytes was found to be significantly higher in COVID-19 patients and their higher percentages were correlated with disease severity $[38,52]$. Whereas the study by Schulte-Schrepping et al. underlined a particular depletion of non-classical monocytes with an upregulated expression of tissue infiltration and retention markers (CD69 and CD226) in severe COVID-19 [53]. A significant decrease in transitional and non-classical monocytes in peripheral blood [54] together with the significant abundance of these monocyte subsets in bronchoalveolar samples [54, 55] of COVID-19 cases with increasing severity was also reported. Taken together, these studies seem to tell different parts of the same story, most likely due to the differences in the timing of sample collection of the studies. Although it would be possible to understand the exact situation only with further studies.

The peculiar immune-dysregulation pattern in most of the severe COVID-19 patients was distinctive with hypersecretion of IL- 6 by monocytes despite diminished antigen presentation [56]. The prevailing conclusion from many other studies for the cytokine storm of COVID-19 is that the higher the IL- 6 secretion by mainly monocytes, the more severe the clinical picture $[52,54,57,58]$. High IL-6 levels associated with lowered expression of HLA-DR molecule by monocytes which was shown to be reversed by IL- 6 blockage [56]. This situation constitutes an important weak spot of the immune system in coping with SARS-CoV-2 due to its disrupting of the development of an effective adaptive immune response and its negative correlation with lymphopenia (Fig. 2).

The fact that the alterations in monocytes with aging demonstrate sex-dependent diversity to the detriment of males $[49,59]$ not only explains the higher predisposition of aged men to diseases with chronic inflammatory pathogenesis such as cardiovascular disease but also overlaps with the higher COVID-19-related mortality risk of male sex [60].

Overall, being pivotal elements of innate immunity, monocytes and macrophages are of special importance for intricate interrelations of cellular senescence-inflammagingand immunosenescence $[49,51,57]$ and therefore the emergence of cytokine storm which is the characteristic pathophysiology in severe COVID-19 [57, 61]. Since they constitute both the very first line of defense in innate immunity and the regulatory cells for the adaptive immunity to generate specific immune response, monocytes and macrophages appear to be decisive for the severity of the clinical picture [62]. They play the leading role in both mechanisms that lead COVID-19 patients to respiratory failure: either macrophage activation syndrome $[56,63]$ or the unique immune dysregulation pattern characterized by monocyte hyperactivation and increased IL-6 secretion despite defective antigen presentation [56]. In addition, monocytes, through their interactions with platelets, play a critical role in the hypercoagulability and associated complications seen in severe disease [64].

\subsubsection{Adaptive immunity (T- and B-cells)}

Adaptive immune system which has the aptitude to develop superbly specific immune responses through its cell-mediated and humoral arms in cooperation with innate immunity weakens with aging. As expected, age-related deterioration in antigen presentation and preceding steps also blunts T-cell activation and expansion [31]. Increase in memory cells and decrease in naïve cells are the fundamental alterations of $\mathrm{T}$ lymphocytes in the course of immunosenescence [65]. Age-related thymic involution and functional impairment of its remaining reserve do not merely result in decreased naïve $\mathrm{T}$-cell production, but also lower inducible regulatory $\mathrm{T}\left(\mathrm{T}_{\text {reg }}\right)$ cells and anti-inflammatory cytokine secretion [66] (Fig. 2). As thymus size and function are controlled by multiple factors like sex hormones, stress factors, metabolic hormones and adiposity, these changes might appear at varying rates between individuals [66] and contribute to inflammaging, impair effective immune responses to novel antigens and vaccines in older adults whereas memory responses are preserved [30]. Besides, costimulatory molecule CD28 expression decreases and telomere shortening is observed in senescent T-cells [67]. CD28 loss is characterized by inability of senescent T-cells to proliferate due to decreased telomerase activity, and nonspecific cytotoxicity in a manner like Natural Killer (NK) cells via recognition of NK-Cell receptors [68]. Therefore, senescent $\mathrm{T}$ lymphocyte repertoire is already disadvantageous in dealing with SARS-CoV-2 [25]. On top of that, in case of severe COVID-19 characterized by uncontrolled inflammatory cytokine release and lymphocytopenia [38], granulocyte-macrophage colony-stimulating factor-overexpressing pathogenic $\mathrm{CD} 4^{+} \mathrm{Th} 1$ cells, activated cytotoxic $\mathrm{CD}^{+}{ }^{+}$-cells and $\mathrm{CD} 28^{-}$NK-like T-cells were shown to have significantly increased proportion and so contributed to inflammatory damage by migration to lungs and other tissues and triggering further cytokine secretion $[52,54,69]$. T-cell exhaustion which means reduced functionality is another indicator of immunosenescence [25] and T-cell exhaustion markers PD-1 and TIM3 are expressed in higher levels with increasing COVID-19 severity [52, 70] (Fig. 2). 
Vitamin D insufficiency is known to be associated with increased susceptibility to upper respiratory infections and several COVID-19 risk factors [71-73]. Age-related hypovitaminosis $\mathrm{D}$ due to both its decreased production in the aging-skin and diminished bioavailability has negative effects on immunomodulation like dysregulation of T cell-driven inflammation via $\mathrm{T}_{\text {reg }}$ cells [71].

In addition to disturbance of interactions with T-cells and innate immunity, B-cells are also altered during immunosenescence in terms of their subtype proportions and functions: Naïve B-cells decrease in number, their class-switching and somatic hypermutation functions are impaired, and age-associated B-cells (ABCs) which constitute an atypical subset of memory B-cells accumulate [25, 74]. Therefore, specific antibody production in response to first encounter with a new pathogen or vaccine fails and clonally expanded B-cells enhance the chronic inflammation of aging [74, 75]. Moreover, obesity-associated chronic inflammation, which imitates inflammaging, is an important risk factor for accelerated B-cell aging [76]. In the course of severe COVID19 , number of B-cells and plasmablasts was found to be increased, however it was not coupled with an increased immunoglobulin production [38]. Older COVID-19 patients demonstrated augmentation of age-related changes in B-cell subtypes: decreased naïve B-cells and increased ABCs [25] (Fig. 2). Novel data about sex-specific changes in immune aging revealed that B-cell specific genes were inactivated in older males whereas activated in females [59]. This finding is noteworthy as it overlaps with the knowledge of the more severe disease course and increased mortality rate of males in COVID-19 [60].

\section{Hormonal changes in the elderly and COVID-19 and their relevance with immunological alterations}

\subsection{Renin-angiotensin-aldosterone system}

ACE2 is a membrane-bound and secreted carboxypeptidase capable of cleaving Angiotensin (Ang)-I into Ang-(1-9) [77], Ang-II to Ang-(1-7) [78], and degrading des-Arg-bradykinin [77]. ACE2 is expressed in a wide variety of tissues, including nasopharynx, lungs, gastrointestinal system, adipose tissue, heart and vessels, eyes, thyroid gland, pancreas, male and female reproductive system, kidneys, and skin [4]. Vasodilatory, anti-inflammatory and anti-fibrotic effects of ACE2 through Ang-(1-7)/Mas receptor axis of renin-angiotensinaldosterone system (RAAS) have led investigators to consider ACE2 a potential therapeutic target for cardiovascular diseases [79]. ACE2 has become a hot topic for research once again in 2003 and 2019, when it was realized that SARS-CoV and SARS-CoV-2 used ACE2 to infect human cells [3].
After binding of the viral spike (S) protein to cellular ACE2 receptor, SARS-CoV-2 needs to use TMPRSS2, the serine protease of the host, for a process called ' $S$ priming'. Together, ACE2 and TMPRSS2 are the main proteins for the entry of SARS-CoV-2 into the target cells [3]. The interaction between viral S protein and ACE2 translate into a crosstalk between viral infection and RAAS via the downregulation of ACE2. As a result, SARS CoV-2 infection causes a shift in the RAAS from ACE2/Ang-(1-7)/Mas receptor axis to ACE/Ang-II/Angiotensin Receptor (AT)-1 axis with vasoconstrictor, pro-inflammatory and pro-fibrotic effects. These changes are highly important in the pathogenesis of endothelial injury and ARDS in COVID-19 [7].

SARS-CoV-2 may also directly infect endothelial cells through endothelial ACE2, as demonstrated by postmortem histopathological examinations in a group of critically ill patients [80]. Endotheliitis-related endothelial damage, upregulation of bradykinin system due to reduced degradation by ACE2, and Ang-II-induced neutrophil accumulation characterized with increased secretion of pro-inflammatory cytokines would lead to vascular leakage, alveolar edema and severe inflammation in the lungs, and may progress to ARDS and cytokine storm [7, 81]. Disruption of endothelial integrity may activate the coagulation cascade and result in thrombotic events. [81]. Older age [82] and conditions like metabolic syndrome (MetS), hypertension, obesity and diabetes are characterized with pre-existent endothelial dysfunction, and may be the reason for rapid progression to severe COVID-19 [81, 83].

Molecular mechanisms of aging such as cumulative oxidative stress and inflammaging also are involved in the mechanisms underlying age-related endothelial dysfunction [84]. Ang-II contributes to endothelial dysfunction by increasing the production of reactive oxygen species that leads to decreased synthesis of endothelial nitric oxide, which typically has vasoprotective, anti-inflammatory and anti-thrombotic effects [85]. COVID-19 may accelerate and/ or deteriorate pre-existing endothelial dysfunction in older patients via Ang-II-associated mechanisms. Together with microvascular endothelial dysfunction, age-related impairment in angiogenesis is associated with disrupted adaptation to tissue hypoxia and decreased ability to recover after tissue damage [82], both of which may facilitate MOF process in severe COVID-19 (Fig. 3).

It was speculated that either high or low ACE2 expression might be related to COVID-19 disease susceptibility and/or severity. Despite the lack of evidence, animal models revealed that lower ACE2 expression might be involved in lung damage [86, 87]. The higher rates of severe COVID-19 in older population and patients with certain comorbidities underpin this hypothesis. In support of this assumption, agerelated reduction was observed in ACE2 expression in lungs of mice, more significantly in males compared to females 


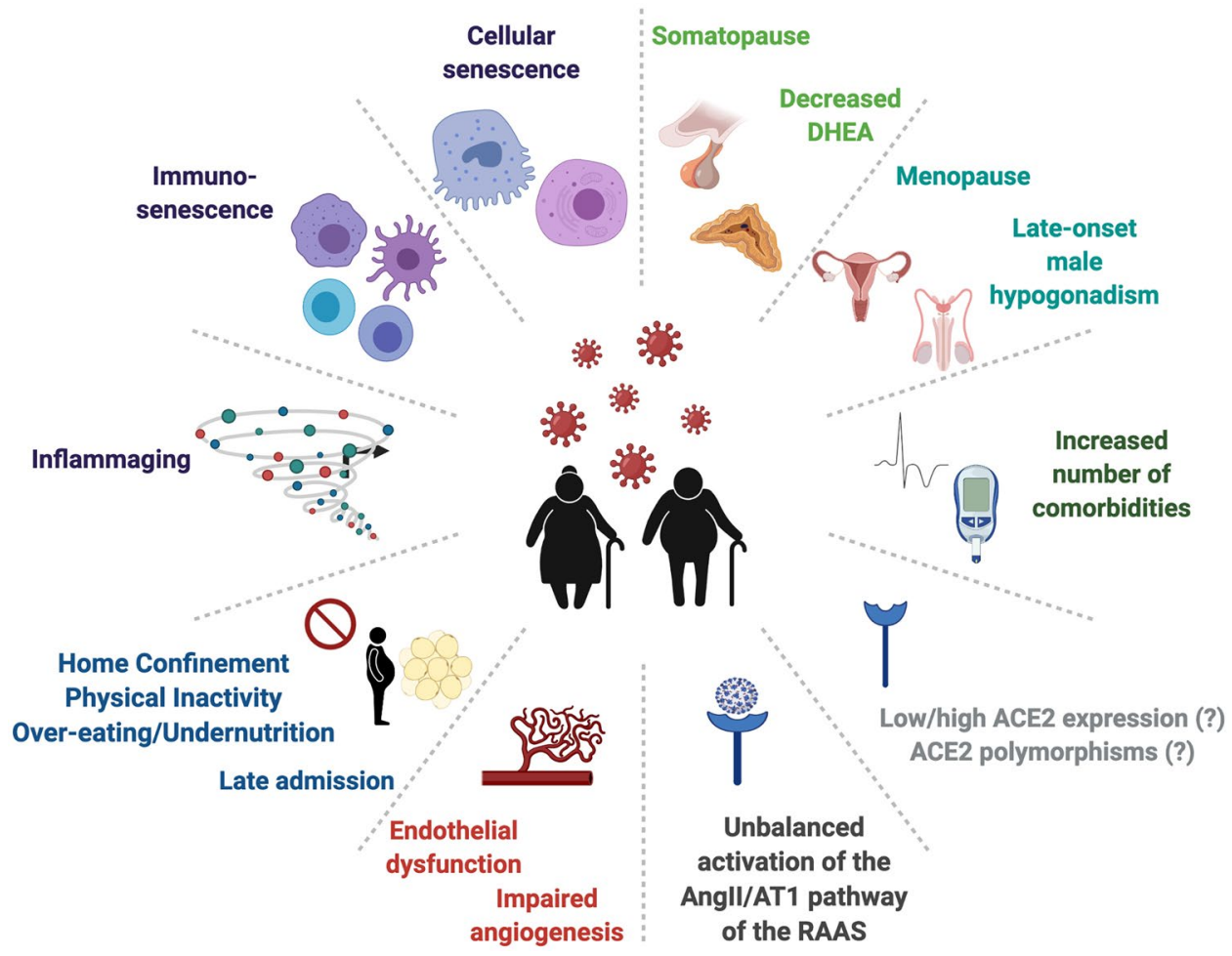

Fig. 3 Age-related endocrine and immunologic factors leading to severe COVID-19. Unfavorable aging-related changes in the immune system, age-related hormonal alterations, increased number of comorbidities along with visceral adiposity and related disorders conspire to vulnerability of older adults to severe COVID-19. In addition, older age (cumulative oxidative stress and inflammaging) and certain comorbidities (e.g. diabetes and cardiovascular diseases) already char-

[88]. A similar trend was discovered in human tissues as well [89]. Another speculation was that single nucleotide polymorphisms of ACE2 or TMPRSS2 may be linked to COVID-19 severity, possibly in a manner to the detriment of men [90]. However, to date, none were identified [91].

In conclusion, the interaction between viral $\mathrm{S}$ protein and the RAAS, and subsequent cascade of events represent the main pathological mechanism in COVID-19. Older patients appear to be more vulnerable to severe disease due to already existing endothelial dysfunction, impaired angiogenesis and possibly low expression of ACE2. At the time of preparing this review, there were ongoing clinical trials aiming to investigate the effect of kinin blockage (NCT04549922) and recombinant ACE2 receptors in COVID-19 (NCT04375046, NCT04382950, NCT04672395, NCT04287686).

\subsection{Sex hormones, aging and COVID-19}

Men and women have documented clinical disparities in many viral respiratory infections, including Influenza A Virus [92], SARS-CoV [93] Middle East Respiratory Syndrome Coronavirus [94] and SARS-CoV-2 [8, 95]. Higher acterized with endothelial dysfunction accompanied by age-related impairment in angiogenesis are the other links of this chain of events leading to severe COVID-19. COVID-19: Coronavirus disease 2019; ACE2: Angiotensin converting enzyme 2; Ang-II: Angiotensin-II; AT-1: Angiotensin receptor-1; RAAS: Renin-angiotensin-aldosterone system; GH: Growth hormone; DHEA: Dehydroepiandrosterone

case-fatality rates were reported for male patients worldwide during COVID-19 pandemic, despite comparable test positivity among male and female subjects $[96,97]$, or even higher positivity in younger women in some reports $[98,99]$. Male predisposition persists but tends to decline in older ages, yet senescence is associated with mortality in both sexes [100]. While higher rates of smoking [97], greater number of co-morbid diseases [73, 101], and various social factors including the compliance to protective measures [102] may have some influence on susceptibility to severe disease in men; the impact of sex hormones on immune response against COVID-19 infection has become a focus area.

Sex steroids regulate immune responses via interacting with their receptors expressed by immune cells. Overall, androgens and progesterone have anti-inflammatory effects whereas estrogen has both anti- and pro-inflammatory effects in high and low concentrations, respectively [103, 104].

Innate immunity is stronger in women than men in general. By stimulating numerous pro-inflammatory cytokines including IFN-I, IL-6 and Tumor Necrosis Factor (TNF)- $\alpha$, and by activating monocytes, macrophages and NK cells, 
estrogen in low concentrations enhances innate immune responses and also increases the differentiation of DCs for better antigen presentation to naïve T-cells [103]. Androgens, on the other hand, have almost the opposite effects on innate immunity [104]. While a more active innate immune system might indicate a female advantage over initial immune responses against pathogens, if dysregulated, consecutive hyperactivation of T-cells and excessive release of cytokines can ultimately invoke cytokine storm. Conformably, in deteriorating female COVID-19 patients, levels of innate immune cytokines were significantly increased [105]. Yet, in older COVID-19 patients, IL-6 concentrations were higher in males compared to females [106, 107], suggesting damaged pulmonary and/or endothelial cells may be the main sources of certain cytokines during severe COVID-19 [38].

Lymphopenia, a typical sign in viral infections, tends to be more severe and long-lasting in COVID-19 [108]. Although the mechanism has not been fully determined, lymphopenia is an indicator of poor prognosis over the course of COVID-19 [11, 107]. Male and older patients have more severe COVID-19-associated lymphopenia [107], which may be, at least in part, due to above-mentioned cellular senescence mechanisms, including TL disadvantage of male sex and older age [20]. While postmenopausal women have lower counts of $\mathrm{B}$ and $\mathrm{CD} 4^{+} \mathrm{T}$ lymphocytes compared to pre-menopausal women in general [109], Takahashi T, et al. reported still greater T-cell response in older females than male COVID-19 subjects, characterized with a higher number of activated and terminally differentiated $\mathrm{CD} 8^{+} \mathrm{T}$-cells in females. The investigators reported that compared to women, the relation of aging with impaired immune responses was more pronounced in men infected with SARS-CoV-2 [105].

Estrogen increases the number, activation, maturation, and survival of antibody-producing peripheral B-cells, characterized by higher immunoglobulin and antibody responses to pathogens and vaccines $[103,110,111]$. Although aging is associated with diminished regeneration and repertoire diversity of B-cells resulting in decreased antibody production in both sexes $[75,112]$, higher antibody titers were still observed in older women after seasonal Influenza vaccination compared to older men [113]. In accordance, an earlier increase and higher levels of $\operatorname{IgG}$ antibodies were detected in female subjects compared to men having severe COVID19 [114]. Hopefully, whether the COVID-19 vaccine will induce different antibody titers in men and women in accordance with age will be reported in the future.

In both sexes, sex hormone levels decrease with age, quite rapidly in females and steadily in males. In vivo studies have shown increased levels of IL- 6 and TNF- $\alpha$ in the postmenopausal period $[115,116]$, and a number of studies have reported decreasing IL-6 levels with short-term hormone replacement therapy (HRT) $[117,118]$. Regarding COVID19, a large retrospective study has reported increasing fatality rates among women above the age 60 despite decreasing prevalence relative to younger women [99]. Of note, another retrospective study has disclosed a substantial reduction in the fatality risk (6.6\% to $2.3 \%$ ) in peri- and postmenopausal women on HRT compared to non-users [119]. However, neither of these studies have evaluated other confounding factors, comorbidities or cytokine levels. A cross-sectional analysis comparing pre- and post-menopausal patients under 60 years of age indicated that higher levels of estradiol were associated with lower levels of pro-inflammatory cytokines and better outcomes [120]. While the effects of estrogen treatment on COVID-19 are being studied in ongoing clinical trials, here appears a controversy regarding the abovementioned favorable effects of low estradiol concentrations on immune responses. Moreover, given the increased risk of coagulopathy in COVID-19 [121], starting HRT in patients infected with SARS-CoV-2 may be risky. Even so, Italian Menopause Society recommended to continue HRT in women with mild COVID-19, but to consider switching to transdermal route [122].

Serum total and free testosterone levels decline continuously in men with aging. Up to $50 \%$ of men over the age of 80 would have low concentrations of serum testosterone [123]. Although male gender appears to be an independent risk factor for COVID-19 mortality irrespective of comorbidities in any decade of life [12], it remains controversial whether the suppressive effects of androgens on immune responses can play a role on disease severity. Some reports have indicated a worse course of disease in male patients with higher levels of testosterone and better outcomes in male patients using androgen deprivation therapies [124, 125]. However, these data do not explain why older males having supposedly lower androgen levels have poorer prognosis than younger men [126]. A more credible perspective may be that age-related hypogonadism in men is associated with MetS and related disorders [127], which are common comorbidities in patients with severe COVID-19 (Fig. 3). In line with this assumption, there are reports on the association between low testosterone concentrations and poor COVID19 outcomes in men [128, 129]. These studies, however, included a limited number of patients and did not adjust their results according to either the age or body mass index (BMI). In fact, hypogonadism may not be the reason but the consequence of the severe inflammatory condition [130]. In general population of hypogonadal men with MetS, studies were contradictory regarding the effect of testosterone replacement on pro-inflammatory cytokine levels [131-133]. To date, no studies are investigating the effect of androgen replacement therapies in male COVID-19 patients.

In conclusion, given the controversies over potential beneficial immunogenic effects of both low and high sex 
steroid concentrations and the lack of prospective randomized controlled trials, it is difficult to relate the unfavorable COVID-19 outcomes in male patients only to the effects of sex steroids. However, sex hormones may still be involved in some of the certain immunological disparities among men and women. Nevertheless, as this review is being written, estrogen (NCT04539626, NCT04359329), progesterone (NCT04365127) and antiandrogen (NCT04446429, NCT04509999, NCT04397718, NCT04475601, NCT04374279, NCT04652765) agents are being investigated in COVID-19 clinical trials. As we continue to wait for the results of these ongoing trials, one pre-print study revealed no in vitro anti-viral activity with interventions causing an increase or decrease in sex steroid hormones [134].

\subsection{Anabolic hormones, sarcopenic obesity, aging and COVID-19}

Age-related constant decline in anabolic hormones plays a role in the development of sarcopenia in older adults. Aging is associated with 'a progressive increase in the ratio between fat and lean body mass', and occurrence of visceral and ectopic fat accumulation, which may lead to sarcopenic obesity [135]. Since BMI fails to determine sarcopenic obesity in the elderly, it could be overlooked without anthropometric measurements [136]. Age-related decline in sex steroids, growth hormone $(\mathrm{GH})$ and vitamin D contribute to the changes in body composition, along with reduced sensitivity to thyroid hormones and leptin [72, 135]. Changes in body composition with advancing age are similar to those in GH deficiency [137], menopause [138], and late-onset hypogonadism in males [139]. Although no studies have yet evaluated the effects of either sarcopenia or sarcopenic obesity on COVID-19 outcomes, it was suggested to consider both [140, 141] as risk factors for severe disease (Fig. 4).

Sarcopenia is defined as a 'progressive and generalized skeletal muscle disorder that is associated with increased likelihood of adverse outcomes including falls, fractures, physical disability and mortality', according to European Working Group on Sarcopenia in Older People [142]. Estimated prevalence of sarcopenia and sarcopenic obesity increases with age and ranges from $2.75 \%$ to $20 \%$, depending on the criteria used. Studies have reported either increased, decreased or similar frequency between men and women $[136,143]$. Sarcopenia may be associated with a decrease in respiratory muscle strength in the elderly [144], and may cause an increase in the risk of respiratory infections [145], prolonged stay in the intensive care unit (ICU), difficulty in weaning from invasive mechanical ventilation (IMV) [146], and both in-hospital [147] and long-term mortality [148]. Even if not present on admission, elderly patients may become sarcopenic during hospital stay $[149,150]$. Acute sarcopenia, lasting less than 6 months usually because of an acute illness [142], may develop in days spent in bed rest $[149,151]$. It was suggested that COVID-19 might also result in sarcopenia in short- [152] and long-term [153], and might contribute to poor disease outcomes [154].

Restrictions and 'stay home' measures starting with the declaration of COVID-19 pandemic have led to increased physical inactivity (Figs. 3, 4). Online surveys revealed that all kinds of physical activity declined whereas sedentary time increased along with overeating and unhealthy eating behavior $[155,156]$. In addition, lower vitamin D synthesis in the elderly, together with decreased exposure to sunlight due to home confinement, would result in hypovitaminosis $\mathrm{D}$, which is linked to lower muscle mass and sarcopenia [72]. Sleep duration and quality were also depleted, in a negatively correlated manner with weight gain and age [156]. Physical inactivity effects the elderly in a more rapid and irrecoverable manner than the young in regards of worsening metabolic parameters, increasing inflammatory cytokines, and a reduction in muscle protein synthesis $[157,158]$. With stress creating a proinflammatory environment [159] and the need to overcome the stress by translating it into an unhealthy eating behavior [160], and given the fact that already overweight adults gaining much more weight in the time of COVID19 restrictions [156], there appears the risk of sarcopenic obesity and interconnected metabolic disorders. Contrarily, older adults may also be at the risk of undernutritionassociated sarcopenia due to lower income/unemployment and/or limited access to food markets. In either way, if infected with SARS-CoV-2, increased levels of inflammatory cytokines, especially TNF- $\alpha$, would contribute to catabolism in skeletal muscle [161], possibly including diaphragm muscle fibers and thus may compound respiratory muscle weakness in the elderly [162].

Longer length of hospitalization, and higher rates of ICU admission and IMV are expected in older adults with COVID-19 [10]. Notably, it was suggested that acute sarcopenia may aggravate more rapidly if chronic sarcopenia is already existent in older adults [163]. Older men may be at a disadvantage compared to women, since hospitalization was related to greater loss of lean mass rather than fat mass in only male subjects [164], and critically ill men were more frequently miscategorized as non-sarcopenic according to subjective indexes [165]. There is no data upon neither the prevalence of sarcopenia or sarcopenic obesity in older patients with COVID-19, or the effect of those on disease outcomes; however, it seems justifiable to assume a comparable prevalence and consequential increased mortality as reported in earlier studies [146, 165].

Age-related decline in testosterone and sarcopenic obesity are interrelated. Low testosterone levels are associated with 
Fig. 4 The possible causes and significance of sarcopenia and visceral obesity in poor COVID-19 outcomes. Increased physical inactivity and stress due to home confinement strategies during COVID-19 pandemic may have affected older adults in a more rapid and irrecoverable manner than the young. Along with comorbid diseases, stress-related overeating and age-related hormonal alterations may contribute to the emergence or worsening of visceral fat accumulation, sarcopenia/sarcopenic obesity, and related cardiometabolic disorders. In case of COVID19, sarcopenia would further aggravate and might be related to severe COVID-19 and even death. COVID-19: Coronavirus disease 2019

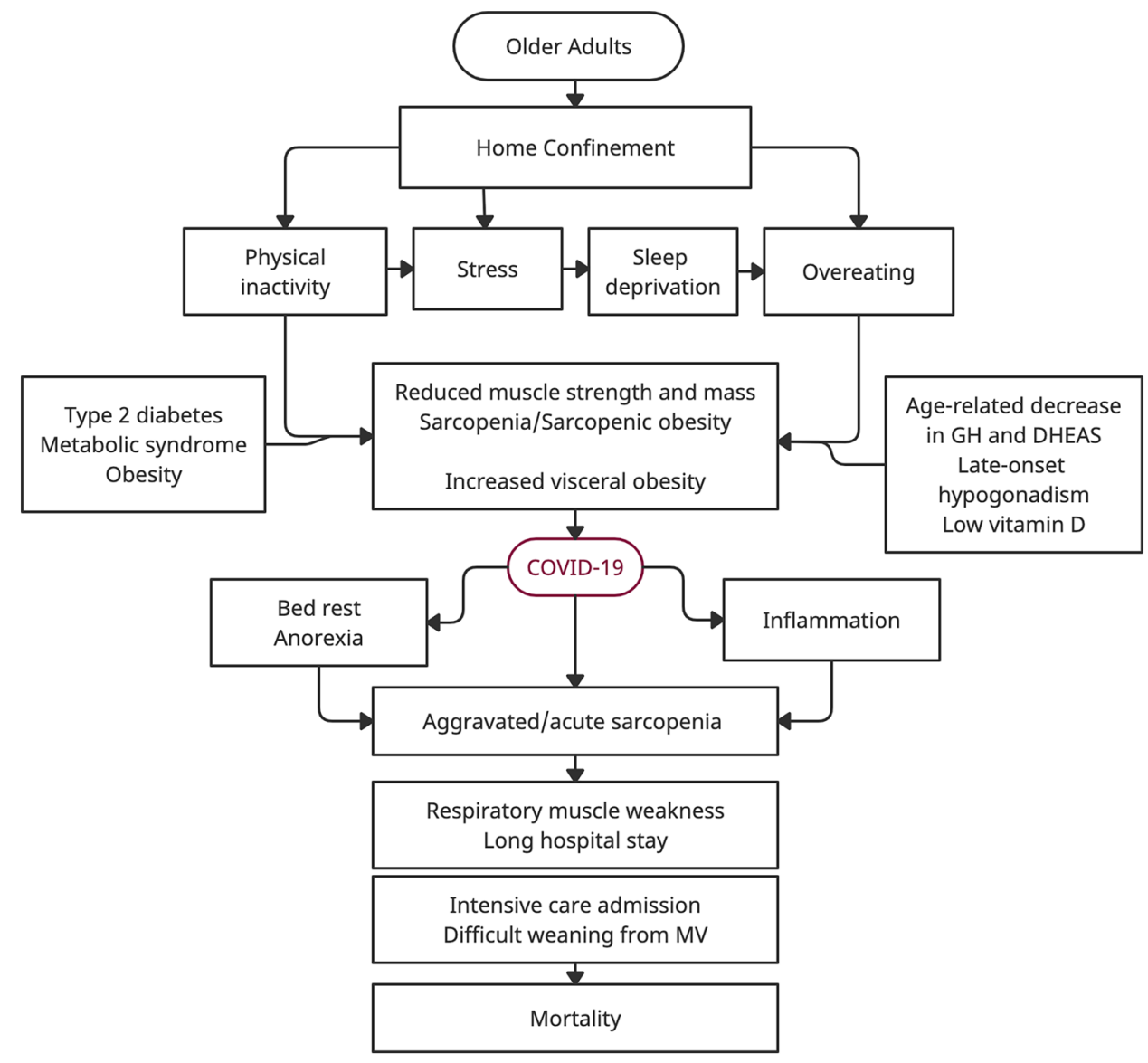

decreased fat-free mass, reduced muscle strength, increased visceral adiposity, insulin resistance, MetS [166, 167], cardiovascular- and all-cause mortality [168]. Furthermore, the curve of age-related decline in serum testosterone becomes steeper in men with abdominal obesity and comorbid diseases [169]. Unlike women, aging men may avoid agerelated hypogonadism with lifestyle modifications, since it is possible to restore testosterone levels by losing weight $[169,170]$. To date, contradictory reports have been published upon the relation between serum testosterone levels and prognosis of COVID-19 [128, 171].

Visceral and truncal fat significantly increase in women after menopause, while leg fat percentage decreases [138]. The changes in the body composition along with inflammation are related to MetS [172]. Unlike men, higher testosterone levels in postmenopausal period have been related to an increase in waist circumference, but not in visceral fat area [173]. Controversy remains upon the relationship between postmenopausal hyperandrogenism and MetS $[174,175]$. The main adrenal sex steroid dehydroepiandrosterone (DHEA) reduces significantly with aging in both sex and negatively correlates with muscle strength $[176,177]$. However, DHEA replacement has not improved body composition, insulin sensitivity or physical performance in a general population of elderly men and women [178].
Age-related decline in $\mathrm{GH}$ and accompanying frailty is referred to 'somatopause'. While age-related decline in GH levels has been attributed to decreased release of GH releasing hormone and increased somatostatin [179], multiple other factors regulate $\mathrm{GH}$ secretion including abdominal obesity, gender, sex steroids, nutritional status, sleep, stress and exercise [180]. Somatopause is associated with decreased lean body mass, increased body fat mass, and reduced exercise capacity, leading to frailty, sarcopenia and abdominal obesity [180]. Home confinement measures during COVID-19 may have intensified the effects of GH deficiency in the elderly.

Somatopause is involved in immunosenescence, since GH axis regulates immune responses [181]. The main immune role of GH is to induce thymic output. Thus, somatopause is associated with thymic involution and decreased production of naïve T-cells. GH also enhances the maturation of antigen presenting DCs and differentiation of B-cells, as well as TNF- $\alpha$ production by monocyte/macrophages [181]. Ghrelin, which is a stimulator of both GH release and thymogenesis, also reduces with advancing age. Decreased appetite and energy expenditure in older adults, in part, are attributed to decreased ghrelin levels [182]. Thus, anorexic effects of COVID-19 might be exaggerated in the elderly with reduced ghrelin levels. 
Cortisol secretion increases gradually with advancing age, mainly after the age of 60 in both sexes [183]. Studies investigating the effect of endogenous corticosteroids on muscle mass and strength in older adults are controversial [176, $177,184]$. TNF- $\alpha$ induces the activity of $11 \beta$-hydroxysteroid dehydrogenase-1 (11ßHSD1) [185]. Higher expression of $11 \beta$ HSD1 in skeletal muscle was associated with reduced muscle strength in older adults [186], insulin resistance, and visceral fat accumulation [187]; thus with metabolic disturbances and possibly sarcopenic obesity.

Recently, several publications have reported an association between COVID-19 severity and visceral adiposity [188-193], which might have been the very missing link connecting advanced age, age-related hormonal changes, and cardiometabolic disorders together as risk factors for COVID-19 severity. Because the shared finding in all these conditions is redistribution of fat to intraabdominal visceral area. Although women have higher percentage of total body fat throughout the lifespan, adipose tissue preferentially accumulates superficially at the subcutaneous intraabdominal and gluteo-femoral areas, not at the visceral area. Men generally have greater total visceral adipose tissue area compared to women [194, 195]. After menopause, redistribution of body fat from subcutaneous to intra-abdominal visceral area occurs [196]. Visceral fat accumulation is associated with a characteristic pro-inflammatory and procoagulant state [197, 198]; which may contribute to disease severity in COVID-19 [9, 199] (Fig. 3). In addition, the expression of ACE2 in the adipose tissue may be important regarding COVID-19 [4]. High fat diet-induced obesity in mice resulted in upregulation of ACE2 expression in the lung epithelium. In vitro experiments in human lung epithelium displayed higher ACE2 expression in obese subjects [200], which might increase the susceptibility to SARSCoV-2 infection [201], as it did in SARS-CoV [202].

Visceral fat area has been suggested as the best predictor of ICU admission in COVID-19 [193]. A meta-analysis $(n=560)$ revealed that patients requiring ICU or IMV had significantly higher visceral fat area while subcutaneous fat area was not associated with severe disease [203]. Of note, mean age of the subjects was 60-65 years in most of the studies [188-190]. None evaluated the patients for sarcopenia, yet one reported that patients with increased intramuscular fat deposition were more likely to have critical illness [191]. Two studies reported that the relationship between visceral fat area and COVID-19 severity was preserved after adjusting the data for age and gender [189-191].

Overall, late-onset hypogonadism/menopause, somatopause and cortisol hypersecretion contribute to age-related changes in body composition by mainly generating central obesity, loss of skeletal muscle mass and function; which indicate sarcopenia or sarcopenic obesity. Physical inactivity, overeating or undernutrition, stress and sleep deprivation during COVID-19 restrictions may aggravate sarcopenia. Moreover, older patients infected with SARS-CoV-2 may rapidly develop acute sarcopenia or worsening of chronic sarcopenia, either might result in elongated hospital stay, requirement for ICU and/or IMV, and mortality. Besides, MetS, diabetes, cardiovascular diseases, pro-inflammatory and procoagulant state in relation to visceral obesity may also negatively affect disease outcomes (Fig. 4). Recently, publications have implicated visceral obesity as a strong indicator of severe COVID-19. The possible significance of visceral adiposity in COVID-19 certainly needs more attention, that we believe would attract in future studies.

\section{Conclusions}

COVID-19 has showed up virtually as an "age-related infection" since its severe progression was encountered predominantly in older patients. Senescent cell burden and immunosenescence which are furthered in male sex and with presence of aging-related comorbidities, increase susceptibility to SARS$\mathrm{CoV}-2$ and facilitate its replication and severe progression. From innate immune responses and antigen presentation to generation of specific cellular and humoral defenses, almost every step that is dysregulated via immunosenescence seems to be further degenerated with COVID-19 and results in poor outcomes. Being the gateway for SARS-CoV-2, ACE2 has a pivotal role to determine disease progression with its vasoactive properties in RAAS and interactions with immune pathways during aging. Although the extent to which the observation of COVID-19 is more severe in older men is related to the sex steroid alterations, it is apparent that changing levels of these hormones with aging influences the shaping of immunosenescence differently for two sexes. Somatopause and increasing cortisol levels with aging are both inducers of thymic involution and they cause the change in body composition favoring visceral adiposity and causing sarcopenia which is the main indication of frailty: decrease in physiological reserves and increased vulnerability to stressors, such as SARS-CoV-2. Abdominal obesity and related inflammation also constitute an important risk factor for severe COVID-19. In summary, immune and endocrine systems work interdependently with the main drive of achieving homeostasis against any stress/ stimuli. Age-related alterations in both these systems and whole organism are shaped with their reciprocal influence.

\section{Future perspectives}

As we have left a year with COVID-19 behind, there have been an abundance of research which shed some light on prevention, pathogenesis, immune responses and prognostic risk factors of the disease. Increased vulnerability leading to severe COVID-19 with poor prognosis in aging population requires urgent attention. While global COVID-19 
vaccination has been continuing, effectiveness of different kinds of vaccines in older adults still requires further investigation. Even though most of the poor prognostic COVID19 risk factors such as endothelial dysfunction, pre-existing comorbidities, immunosenescence, age-related hormonal alterations and change in body composition are unalterable in older adults, given the fact that the prognosis has been relatively good in some elderly patients, the underpins of individual disparities should be addressed. While treatment strategies to prevent severe infection have been under investigation, more research would be made on agents to block the viral $S$ protein-ACE2 interaction since older adults are especially vulnerable to the activation of RAAS cascade and consecutive series of catastrophic events. More research is required on the parameters for deciding which patient would improve with a given treatment, and the timing of cytokine suppressing agents. It would be intriguing to examine the possible effects of senolytic agents or IFN modulators. Although age-related hormonal alterations play an important role on vulnerability to COVID-19, current data is not sufficient to suggest hormone replacement strategies. Nevertheless, every possible effort should be made to avoid sarcopenia and increased visceral adiposity during home confinement, which is only possible with the measures to be taken by governments. Long-term monitorization of older adults is certainly needed to understand if COVID-19 has permanent effects.

Abbreviations 11 $\beta$ HSD1: $11 \beta$-Hydroxysteroid dehydrogenase-1; ABC: Age-associated B-cell; ACE2: Angiotensin-converting enzyme 2; Ang: Angiotensin; APC: Antigen presenting cell; ARDS: Acute respiratory distress syndrome; AT: Angiotensin Receptor; BMI: Body mass index; CD: Cluster of differentiation; COVID-19: Coronavirus Disease of 2019; DC: Dendritic cell; DHEA: Dehydroepiandrosterone; GH: Growth hormone; HLA-DR: Human leukocyte antigen - DR isotype; HRT: Hormone replacement therapy; ICU: Intensive care unit; IFN: Interferon; IL: Interleukin; IMV: Invasive mechanical ventilation; MetS: Metabolic syndrome; MOF: Multi-organ failure; NF-кB: Nuclear factor-kappa B; NK: Natural Killer; PD-1: Programmed Death 1; pDC: Plasmacytoid dendritic cell; PRR: Pattern recognition receptors; RAAS: Renin-angiotensin-aldosterone system; RLR: RIG-1-like receptor; RNA: Ribonucleic acid; SASP: Senescenceassociated secretory phenotype; SARS: Severe Acute Respiratory Syndrome; SARS-CoV: Severe Acute Respiratory Syndrome Coronavirus; SARS-CoV-2: Severe Acute Respiratory Syndrome Coronavirus-2; Th: T-helper; TIM3: T cell immunoglobulin mucin domain-3; TL: Telomere length; TLR: Toll-like receptor; TMPRSS2: Transmembrane protease/serine subfamily 2; TNF: Tumor Necrosis Factor; $\mathrm{T}_{\text {reg }}$ : Regulatory $\mathrm{T}$ cell

Authors' contributions $\mathrm{SHO}$ and MK contributed equally to this work by performing the literature search and drafting the manuscript. BOY reviewed and revised it critically. All authors read an approved the final version.

Funding The author(s) received no financial support for the authorship, and/or publication of this article.

\section{Declarations}

Ethics approval This article does not contain any studies on animal or human participants performed by any of the authors.

Competing interests The authors have no conflict of interest to declare.

\section{References}

1. Lu R, Zhao X, Li J, Niu P, Yang B, Wu H, et al. Genomic characterisation and epidemiology of 2019 novel coronavirus: implications for virus origins and receptor binding. Lancet. 2020;395(10224):565-74. Epub 2020/02/03. https://doi.org/10. 1016/S0140-6736(20)30251-8. PubMed PMID: 32007145; PubMed Central PMCID: PMCPMC7159086.

2. WHO Coronavirus Disease (COVID-19) Dashboard. https:// covid19.who.int/ [14.02.2021].

3. Hoffmann M, Kleine-Weber H, Schroeder S, Kruger N, Herrler $\mathrm{T}$, Erichsen S, et al. SARS-CoV-2 Cell Entry Depends on ACE2 and TMPRSS2 and Is Blocked by a Clinically Proven Protease Inhibitor. Cell. 2020;181(2):271-80 e8. Epub 2020/03/07. https://doi.org/10.1016/j.cell.2020.02.052. PubMed PMID: 32142651; PubMed Central PMCID: PMCPMC7102627.

4. Gheblawi M, Wang K, Viveiros A, Nguyen Q, Zhong JC, Turner AJ, et al. Angiotensin-Converting Enzyme 2: SARS-CoV-2 Receptor and Regulator of the Renin-Angiotensin System: Celebrating the 20th Anniversary of the Discovery of ACE2. Circ Res. 2020;126(10):1456-74. Epub 2020/04/09. https:// doi.org/10.1161/CIRCRESAHA.120.317015. PubMed PMID: 32264791; PubMed Central PMCID: PMCPMC7188049.

5. Wu Z, McGoogan JM. Characteristics of and Important Lessons From the Coronavirus Disease 2019 (COVID-19) Outbreak in China: Summary of a Report of 72314 Cases From the Chinese Center for Disease Control and Prevention. JAMA. 2020;323(13):1239-42. Epub 2020/02/25. https://doi.org/10. 1001/jama.2020.2648. PubMed PMID: 32091533.

6. Tang Y, Liu J, Zhang D, Xu Z, Ji J, Wen C. Cytokine Storm in COVID-19: The Current Evidence and Treatment Strategies. Front Immunol. 2020;11:1708 (PubMed PMID: 32754163).

7. Costa LB, Perez LG, Palmeira VA, Macedo ECT, Ribeiro VT, Lanza K, et al. Insights on SARS-CoV-2 Molecular Interactions With the Renin-Angiotensin System. Front Cell Dev Biol. 2020;8:559841. Epub 2020/10/13. https://doi.org/10.3389/fcell. 2020.559841. PubMed PMID: 33042994; PubMed Central PMCID: PMCPMC7525006.

8. Rapp JL, Lieberman-Cribbin W, Tuminello S, Taioli E. Male Sex, Severe Obesity, Older Age, and Chronic Kidney Disease Are Associated With COVID-19 Severity and Mortality in New York City. Chest. 2020. Epub 2020/09/01. https://doi.org/10. 1016/j.chest.2020.08.2065. PubMed PMID: 32866462; PubMed Central PMCID: PMCPMC7455228.

9. Ng WH, Tipih T, Makoah NA, Vermeulen JG, Goedhals D, Sempa JB, et al. Comorbidities in SARS-CoV-2 Patients: a Systematic Review and Meta-Analysis. mBio. 2021;12(1). Epub 2021/02/11. https://doi.org/10.1128/mBio.03647-20. PubMed PMID: 33563817.

10. Suleyman G, Fadel RA, Malette KM, Hammond C, Abdulla H, Entz A, et al. Clinical Characteristics and Morbidity Associated With Coronavirus Disease 2019 in a Series of Patients in Metropolitan Detroit. JAMA Netw Open. 2020;3(6):e2012270. Epub 2020/06/17. https://doi.org/10.1001/jamanetworkopen.2020. 12270. PubMed PMID: 32543702; PubMed Central PMCID: PMCPMC7298606. 
11. Gao S, Jiang F, Jin W, Shi Y, Yang L, Xia Y, et al. Risk factors influencing the prognosis of elderly patients infected with COVID-19: a clinical retrospective study in Wuhan, China. Aging (Albany NY). 2020;12(13):12504-16. Epub 2020/07/12. https://doi.org/10.18632/aging.103631. PubMed PMID: 32651993; PubMed Central PMCID: PMCPMC7377843.

12. Goodman KE, Magder LS, Baghdadi JD, Pineles L, Levine AR, Perencevich EN, et al. Impact of Sex and Metabolic Comorbidities on COVID-19 Mortality Risk Across Age Groups: 66,646 Inpatients Across 613 U.S. Hospitals. Clin Infect Dis. 2020. Epub 2020/12/19. https://doi.org/10.1093/cid/ciaa1787. PubMed PMID: 33337474; PubMed Central PMCID: PMCPMC7799326.

13. Fulop T, Larbi A, Hirokawa K, Cohen AA, Witkowski JM. Immunosenescence is both functional/adaptive and dysfunctional/ maladaptive. Seminars in Immunopathology. 2020;42(5):521-36. https://doi.org/10.1007/s00281-020-00818-9.

14. Franceschi C, Garagnani P, Vitale G, Capri M, Salvioli S. Inflammaging and "Garb-aging." Trends Endocrinol Metab. 2017;28(3):199-212 (PubMed PMID: 27789101).

15. Childs BG, Durik M, Baker DJ, van Deursen JM. Cellular senescence in aging and age-related disease: from mechanisms to therapy. Nat Med. 2015;21(12):1424-35 (PubMed PMID: 26646499).

16. Hayflick L. The Limited in Vitro Lifetime of Human Diploid Cell Strains. Exp Cell Res. 1965;37:614-36 (PubMed PMID: 14315085).

17. Lombard DB, Miller RA, Pletcher SD. Biology of Aging and Longevity. In: Halter JB, Ouslander JG, Studenski S, High KP, Asthana S, Supiano MA, et al., editors. Hazzard's Geriatric Medicine and Gerontology, 7e. New York, NY: McGraw-Hill Education; 2017.

18. Froidure A, Mahieu M, Hoton D, Laterre PF, Yombi JC, Koenig $\mathrm{S}$, et al. Short telomeres increase the risk of severe COVID-19. Aging (Albany NY). 2020;12(20):19911-22 (PubMed PMID: 33104521).

19. Sanchez-Vazquez R, Guío-Carrión A, Zapatero-Gaviria A, Martínez P, Blasco MA. Shorter telomere lengths in patients with severe COVID-19 disease. Aging (Albany NY). 2021;13(1):115. Epub 2021/01/12. https://doi.org/10.18632/aging.202463. PubMed PMID: 33428591; PubMed Central PMCID: PMCPMC7835063.

20. Turner KJ, Vasu V, Griffin DK. Telomere Biology and Human Phenotype. Cells. 2019;8(1). Epub 2019/01/24. https://doi.org/ 10.3390/cells8010073. PubMed PMID: 30669451; PubMed Central PMCID: PMCPMC6356320.

21. Ruhland MK, Loza AJ, Capietto AH, Luo X, Knolhoff BL, Flanagan KC, et al. Stromal senescence establishes an immunosuppressive microenvironment that drives tumorigenesis. Nat Commun. 2016;7:11762. Epub 2016/06/09. https://doi.org/10. 1038/ncomms11762. PubMed PMID: 27272654; PubMed Central PMCID: PMCPMC4899869.

22. Nehme J, Borghesan M, Mackedenski S, Bird TG, Demaria M. Cellular senescence as a potential mediator of COVID-19 severity in the elderly. Aging Cell. 2020;19(10):e13237. https://doi. org/10.1111/acel.13237.

23. Frisch SM, MacFawn IP. Type I interferons and related pathways in cell senescence. Aging Cell. 2020;19(10):e13234. https://doi. org/10.1111/acel.13234.

24. Molony RD, Malawista A, Montgomery RR. Reduced dynamic range of antiviral innate immune responses in aging. Exp Gerontol. 2018;107:130-5. https://doi.org/10.1016/j.exger.2017.08.019.

25. Zheng Y, Liu X, Le W, Xie L, Li H, Wen W, et al. A human circulating immune cell landscape in aging and COVID-19. Protein Cell. 2020;11(10):740-70 (PubMed PMID: 32780218).

26. Holder K, Reddy PH. The COVID-19 Effect on the Immune System and Mitochondrial Dynamics in Diabetes, Obesity, and Dementia.
Neuroscientist. 2020;((Holder K.; Reddy P.H., hemachandra. reddy@ttuhsc.edu) Department of Internal Medicine, Texas Tech University Health Sciences Center, Lubbock, TX, United States). https://doi.org/10.1177/1073858420960443.

27. Saleh J, Peyssonnaux C, Singh KK, Edeas M. Mitochondria and microbiota dysfunction in COVID-19 pathogenesis. Mitochondrion. 2020;54:1-7 (PubMed PMID: 32574708).

28. Shaw AC, Bandaranayake T. Immunology of Aging. In: Halter JB, Ouslander JG, Studenski S, High KP, Asthana S, Supiano MA, et al., editors. Hazzard's Geriatric Medicine and Gerontology, 7e. New York, NY: McGraw-Hill Education; 2017.

29. Cunha LL, Perazzio SF, Azzi J, Cravedi P, Riella LV. Remodeling of the Immune Response With Aging: Immunosenescence and Its Potential Impact on COVID-19 Immune Response. Front Immunol. 2020;11:1748 (PubMed PMID: 32849623).

30. Ginaldi L, Loreto MF, Corsi MP, Modesti M, De Martinis M. Immunosenescence and infectious diseases. Microbes Infect. 2001;3(10):851-7 (PubMed PMID: 11580980).

31. Katz JM, Plowden J, Renshaw-Hoelscher M, Lu X, Tumpey TM, Sambhara S. Immunity to influenza: the challenges of protecting an aging population. Immunol Res. 2004;29(13):113-24 (PubMed PMID: 15181275).

32. Metcalf TU, Cubas RA, Ghneim K, Cartwright MJ, Grevenynghe JV, Richner JM, et al. Global analyses revealed age-related alterations in innate immune responses after stimulation of pathogen recognition receptors. Aging Cell. 2015;14(3):42132 (PubMed PMID: 25728020).

33. Blanco-Melo D, Nilsson-Payant BE, Liu WC, Uhl S, Hoagland D, Møller R, et al. Imbalanced Host Response to SARS-CoV-2 Drives Development of COVID-19. Cell. 2020;181(5):1036-45 e9. PubMed PMID: 32416070.

34. Uematsu S, Akira S. Toll-like receptors and Type I interferons. J Biol Chem. 2007;282(21):15319-23 (PubMed PMID: 17395581).

35. Hu W, Yen YT, Singh S, Kao CL, Wu-Hsieh BA. SARS-CoV regulates immune function-related gene expression in human monocytic cells. Viral Immunol. 2012;25(4):277-88 (PubMed PMID: 22876772).

36. Channappanavar R, Fehr AR, Vijay R, Mack M, Zhao J, Meyerholz DK, et al. Dysregulated Type I Interferon and Inflammatory Monocyte-Macrophage Responses Cause Lethal Pneumonia in SARS-CoV-Infected Mice. Cell Host Microbe. 2016;19(2):181-93. Epub 2016/02/13. https://doi.org/10. 1016/j.chom.2016.01.007. PubMed PMID: 26867177; PubMed Central PMCID: PMCPMC4752723.

37. Chu H, Chan JF, Wang Y, Yuen TT, Chai Y, Hou Y, et al. Comparative Replication and Immune Activation Profiles of SARSCoV-2 and SARS-CoV in Human Lungs: An Ex Vivo Study With Implications for the Pathogenesis of COVID-19. Clin Infect Dis. 2020;71(6):1400-9 (PubMed PMID: 32270184).

38. Hadjadj J, Yatim N, Barnabei L, Corneau A, Boussier J, Smith N, et al. Impaired type I interferon activity and inflammatory responses in severe COVID-19 patients. Science. 2020;369(6504):718-24. Epub 2020/07/15. https://doi.org/ 10.1126/science.abc6027. PubMed PMID: 32661059; PubMed Central PMCID: PMCPMC7402632.

39. Pillai PS, Molony RD, Martinod K, Dong H, Pang IK, Tal $\mathrm{MC}$, et al. Mx1 reveals innate pathways to antiviral resistance and lethal influenza disease. Science. 2016;352(6284):463-6. https://doi.org/10.1126/science.aaf3926.

40. To KK, Tsang OT, Leung WS, Tam AR, Wu TC, Lung DC, et al. Temporal profiles of viral load in posterior oropharyngeal saliva samples and serum antibody responses during infection by SARS-CoV-2: an observational cohort study. Lancet Infect Dis. 2020;20(5):565-74 (PubMed PMID: 32213337). 
41. Chen WJ, Yang JY, Lin JH, Fann CS, Osyetrov V, King CC, et al. Nasopharyngeal shedding of severe acute respiratory syndrome-associated coronavirus is associated with genetic polymorphisms. Clin Infect Dis. 2006;42(11):1561-9 (PubMed PMID: 16652313).

42. Reizis B. Plasmacytoid Dendritic Cells: Development, Regulation, and Function. Immunity. 2019;50(1):37-50 (PubMed PMID: 30650380).

43. Della BS. Dendritic Cells and Aging. In: Fulop T, Franceschi C, Hirokawa K, Pawelec G, editors. Handbook of Immunosenescence: Basic Understanding and Clinical Implications. Cham: Springer International Publishing; 2019. p. 651-71.

44. Lloberas J, Tur J, Vico T, Celada A. Molecular and Cellular Aspects of Macrophage Aging. In: Fulop T, Franceschi C, Hirokawa K, Pawelec G, editors. Handbook of Immunosenescence: Basic Understanding and Clinical Implications. Cham: Springer International Publishing; 2019. p. 1631-63.

45. Stout RD, Suttles J. Immunosenescence and macrophage functional plasticity: dysregulation of macrophage function by age-associated microenvironmental changes. Immunol Rev. 2005;205:60-71. Epub 2005/05/11. https://doi.org/10.1111/j. 0105-2896.2005.00260.x. PubMed PMID: 15882345; PubMed Central PMCID: PMCPMC1201508.

46. Locati M, Curtale G, Mantovani A. Diversity, Mechanisms, and Significance of Macrophage Plasticity. Annu Rev Pathol. 2020;15:123-47. Epub 2019/09/19. https://doi.org/10.1146/ annurev-pathmechdis-012418-012718. PubMed PMID: 31530089; PubMed Central PMCID: PMCPMC7176483.

47. Mosley RL. Aging, immunity and neuroendocrine hormones. Adv Neuroimmunol. 1996;6(4):419-32. Epub 1996/01/01. https://doi. org/10.1016/s0960-5428(97)00031-9. PubMed PMID: 9183521.

48. Abassi Z, Knaney Y, Karram T, Heyman SN. The Lung Macrophage in SARS-CoV-2 Infection: A Friend or a Foe? Front Immunol. 2020;11:1312 (PubMed PMID: 32582222).

49. Ginaldi L, De Martinis M. Phenotypic and Functional Changes of Circulating Monocytes in Elderly. In: Fulop T, Franceschi C, Hirokawa K, Pawelec G, editors. Handbook of Immunosenescence: Basic Understanding and Clinical Implications. Cham: Springer International Publishing; 2019. p. 623-50.

50. Hearps AC, Martin GE, Angelovich TA, Cheng W-J, Maisa A, Landay AL, et al. Aging is associated with chronic innate immune activation and dysregulation of monocyte phenotype and function. Aging Cell. 2012;11(5):867-75. https://doi.org/10. 1111/j.1474-9726.2012.00851.x.

51. Ong S-M, Hadadi E, Dang T-M, Yeap W-H, Tan CT-Y, Ng $\mathrm{T}-\mathrm{P}$, et al. The pro-inflammatory phenotype of the human non-classical monocyte subset is attributed to senescence. Cell Death \& Disease. 2018;9(3):266. https://doi.org/10.1038/ s41419-018-0327-1.

52. Zhou Y, Fu B, Zheng X, Wang D, Zhao C, Qi Y, et al. Pathogenic T-cells and inflammatory monocytes incite inflammatory storms in severe COVID-19 patients. Natl Sci Rev. 2020;7(6):998-1002. https://doi.org/10.1093/nsr/nwaa041.

53. Schulte-Schrepping J, Reusch N, Paclik D, Baßler K, Schlickeiser S, Zhang B, et al. Severe COVID-19 Is Marked by a Dysregulated Myeloid Cell Compartment. Cell. 2020;182(6):1419-40 e23. PubMed PMID: 32810438.

54. Sánchez-Cerrillo I, Landete P, Aldave B, Sánchez-Alonso S, Sánchez-Azofra A, Marcos-Jiménez A, et al. COVID-19 severity associates with pulmonary redistribution of CD1c+DCs and inflammatory transitional and nonclassical monocytes. J Clin Invest. 2020;130(12):6290-300 (PubMed PMID: 32784290).

55. Liao M, Liu Y, Yuan J, Wen Y, Xu G, Zhao J, et al. Single-cell landscape of bronchoalveolar immune cells in patients with COVID-19. Nat Med. 2020;26(6):842-4 (PubMed PMID: 32398875).
56. Giamarellos-Bourboulis EJ, Netea MG, Rovina N, Akinosoglou $\mathrm{K}$, Antoniadou A, Antonakos N, et al. Complex Immune Dysregulation in COVID-19 Patients with Severe Respiratory Failure. Cell Host Microbe. 2020;27(6):992-1000 e3. PubMed PMID: 32320677.

57. Pence BD. Severe COVID-19 and aging: are monocytes the key? GeroScience. 2020;42(4):1051-61. https://doi.org/10.1007/ s11357-020-00213-0.

58. McGonagle D, Sharif K, O'Regan A, Bridgewood C. The Role of Cytokines including Interleukin-6 in COVID-19 induced Pneumonia and Macrophage Activation Syndrome-Like Disease. Autoimmun Rev. 2020;19(6):102537 (PubMed PMID: 32251717).

59. Márquez EJ, Chung CH, Marches R, Rossi RJ, Nehar-Belaid D, Eroglu A, et al. Sexual-dimorphism in human immune system aging. Nat Commun. 2020;11(1):751. Epub 2020/02/08. https://doi.org/10.1038/s41467-020-14396-9. PubMed PMID: 32029736; PubMed Central PMCID: PMCPMC7005316.

60. Saghazadeh A, Rezaei N. Immune-epidemiological parameters of the novel coronavirus-a perspective. Expert Rev Clin Immunol. 2020;16(5):465-70. https://doi.org/10.1080/1744666x.2020. 1750954.

61. Merad M, Martin JC. Pathological inflammation in patients with COVID-19: a key role for monocytes and macrophages. Nat Rev Immunol. 2020;20(6):355-62. https://doi.org/10.1038/ s41577-020-0331-4.

62. Jafarzadeh A, Chauhan P, Saha B, Jafarzadeh S, Nemati M. Contribution of monocytes and macrophages to the local tissue inflammation and cytokine storm in COVID-19: Lessons from SARS and MERS, and potential therapeutic interventions. Life Sci. 2020;257:118102 (PubMed PMID: 32687918).

63. Otsuka R, Seino KI. Macrophage activation syndrome and COVID-19. Inflamm Regen. 2020;40:19 (PubMed PMID: 32834892)

64. Hottz ED, Azevedo-Quintanilha IG, Palhinha L, Teixeira L, Barreto EA, Pão CRR, et al. Platelet activation and plateletmonocyte aggregate formation trigger tissue factor expression in patients with severe COVID-19. Blood. 2020;136(11):1330-41 (PubMed PMID: 32678428).

65. Nikolich-Žugich J. The twilight of immunity: emerging concepts in aging of the immune system. Nat Immunol. 2018;19(1):10-9 (PubMed PMID: 29242543).

66. Kellogg C, Equils O. The role of the thymus in COVID-19 disease severity: implications for antibody treatment and immunization. Hum Vaccin Immunother. 2020:1-6. PubMed PMID: 33064620.

67. Bourgeois C, Sauce D. Age-Specific T Cell Homeostasis. In: Fulop T, Franceschi C, Hirokawa K, Pawelec G, editors. Handbook of Immunosenescence: Basic Understanding and Clinical Implications. Cham: Springer International Publishing; 2019. p. 273-301.

68. Griffin P, Michel JJ, Vallejo AN. Diversity of CD28null T Cells in the Elderly: A Glimpse in a Biological Adaptation of Aging. In: Fulop T, Franceschi C, Hirokawa K, Pawelec G, editors. Handbook of Immunosenescence: Basic Understanding and Clinical Implications. Cham: Springer International Publishing; 2019. p. 449-81.

69. Akbar AN, Gilroy DW. Aging immunity may exacerbate COVID19. Science. 2020;369(6501):256-7 (PubMed PMID: 32675364).

70. Diao B, Wang C, Tan Y, Chen X, Liu Y, Ning L, et al. Reduction and Functional Exhaustion of T Cells in Patients With Coronavirus Disease 2019 (COVID-19). Front Immunol. 2020;11:827 (PubMed PMID: 32425950).

71. Bouillon R, Marcocci C, Carmeliet G, Bikle D, White JH, DawsonHughes B, et al. Skeletal and Extraskeletal Actions of Vitamin D: Current Evidence and Outstanding Questions. Endocr Rev. 2019;40(4):1109-51. Epub 2018/10/16. https://doi.org/10.1210/ 
er.2018-00126. PubMed PMID: 30321335; PubMed Central PMCID: PMCPMC6626501.

72. Giustina A. Hypovitaminosis D and the endocrine phenotype of COVID-19. Endocrine. 2021. Epub 2021/03/20. https://doi. org/10.1007/s12020-021-02671-8. PubMed PMID: 33738708; PubMed Central PMCID: PMCPMC7972333.

73. Brandi ML, Giustina A. Sexual Dimorphism of Coronavirus 19 Morbidity and Lethality. Trends Endocrinol Metab. 2020;31(12):918-27. Epub 2020/10/22. https://doi.org/10.1016/j. tem.2020.09.003. PubMed PMID: 33082024; PubMed Central PMCID: PMCPMC7513816.

74. Ma S, Wang C, Mao X, Hao Y. B Cell Dysfunction Associated With Aging and Autoimmune Diseases. Frontiers in Immunology. 2019;10(318). https://doi.org/10.3389/fimmu.2019.00318.

75. Gibson KL, Wu YC, Barnett Y, Duggan O, Vaughan R, Kondeatis E, et al. B-cell diversity decreases in old age and is correlated with poor health status. Aging Cell. 2009;8(1):18-25. Epub 2008/11/07. https://doi.org/10.1111/j.1474-9726.2008. 00443.x. PubMed PMID: 18986373; PubMed Central PMCID: PMCPMC2667647.

76. Frasca D, Diaz A, Romero M, Garcia D, Blomberg BB. B Cell Immunosenescence. Annu Rev Cell Dev Biol. 2020;36(1):55174. https://doi.org/10.1146/annurev-cellbio-011620-034148 (PubMed PMID: 33021823).

77. Donoghue M, Hsieh F, Baronas E, Godbout K, Gosselin M, Stagliano N, et al. A novel angiotensin-converting enzymerelated carboxypeptidase (ACE2) converts angiotensin I to angiotensin 1-9. Circ Res. 2000;87(5):E1-9. Epub 2000/09/02. https:// doi.org/10.1161/01.res.87.5.e1. PubMed PMID: 10969042.

78. Tipnis SR, Hooper NM, Hyde R, Karran E, Christie G, Turner AJ. A human homolog of angiotensin-converting enzyme. Cloning and functional expression as a captopril-insensitive carboxypeptidase. J Biol Chem. 2000;275(43):33238-43. Epub 2000/08/05. https://doi.org/10.1074/jbc.M002615200. PubMed PMID: 10924499.

79. Patel VB, Bodiga S, Fan D, Das SK, Wang Z, Wang W, et al. Cardioprotective effects mediated by angiotensin II type 1 receptor blockade and enhancing angiotensin 1-7 in experimental heart failure in angiotensin-converting enzyme 2-null mice. Hypertension. 2012;59(6):1195-203. Epub 2012/04/18. https://doi.org/ 10.1161/HYPERTENSIONAHA.112.191650. PubMed PMID: 22508831.

80. Varga Z, Flammer AJ, Steiger P, Haberecker M, Andermatt $\mathrm{R}$, Zinkernagel AS, et al. Endothelial cell infection and endotheliitis in COVID-19. Lancet. 2020;395(10234):1417-8. Epub 2020/04/24. https://doi.org/10.1016/S0140-6736(20) 30937-5. PubMed PMID: 32325026; PubMed Central PMCID: PMCPMC7172722.

81. Teuwen LA, Geldhof V, Pasut A, Carmeliet P. COVID-19: the vasculature unleashed. Nat Rev Immunol. 2020;20(7):389-91. Epub 2020/05/23. https://doi.org/10.1038/s41577-020-03430. PubMed PMID: 32439870; PubMed Central PMCID: PMCPMC7240244.

82. Ungvari Z, Tarantini S, Kiss T, Wren JD, Giles CB, Griffin CT, et al. Endothelial dysfunction and angiogenesis impairment in the ageing vasculature. Nat Rev Cardiol. 2018;15(9):555-65. Epub 2018/05/26. https://doi.org/10.1038/s41569-018-0030z. PubMed PMID: 29795441; PubMed Central PMCID: PMCPMC6612360.

83. Hammoud SH, Wehbe Z, Abdelhady S, Kobeissy F, Eid AH, El-Yazbi AF. Dysregulation of Angiotensin Converting Enzyme 2 Expression and Function in Comorbid Disease Conditions Possibly Contributes to Coronavirus Infectious Disease 2019 Complication Severity. Mol Pharmacol. 2021;99(1):17-28. Epub 2020/10/22. https://doi.org/10.1124/molpharm.120.000119. PubMed PMID: 33082267.
84. Ungvari Z, Tarantini S, Sorond F, Merkely B, Csiszar A. Mechanisms of Vascular Aging, A Geroscience Perspective: JACC Focus Seminar. J Am Coll Cardiol. 2020;75(8):931-41. Epub 2020/03/05. https://doi.org/10.1016/j.jacc.2019.11.061. PubMed PMID: 32130929.

85. Herbert KE, Mistry Y, Hastings R, Poolman T, Niklason L, Williams B. Angiotensin II-mediated oxidative DNA damage accelerates cellular senescence in cultured human vascular smooth muscle cells via telomere-dependent and independent pathways. Circ Res. 2008;102(2):201-8. Epub 2007/11/10. https://doi.org/10.1161/CIRCRESAHA. 107. 158626. PubMed PMID: 17991883; PubMed Central PMCID: PMCPMC2861985.

86. Imai Y, Kuba K, Rao S, Huan Y, Guo F, Guan B, et al. Angiotensinconverting enzyme 2 protects from severe acute lung failure. Nature. 2005;436(7047):112-6. Epub 2005/07/08. https://doi. org/10.1038/nature03712. PubMed PMID: 16001071; PubMed Central PMCID: PMCPMC7094998.

87. Sodhi CP, Wohlford-Lenane C, Yamaguchi Y, Prindle T, Fulton WB, Wang S, et al. Attenuation of pulmonary ACE2 activity impairs inactivation of des- $\operatorname{Arg}(9)$ bradykinin/BKB1R axis and facilitates LPS-induced neutrophil infiltration. Am J Physiol Lung Cell Mol Physiol. 2018;314(1):L17-L31. Epub 2017/09/25. https://doi.org/10.1152/ajplung.00498.2016. PubMed PMID: 28935640 ; PubMed Central PMCID: PMCPMC5866432.

88. Xie X, Chen J, Wang X, Zhang F, Liu Y. Age- and genderrelated difference of ACE2 expression in rat lung. Life Sci. 2006;78(19):2166-71. Epub 2005/11/24. https://doi.org/10. 1016/j.1fs.2005.09.038. PubMed PMID: 16303146; PubMed Central PMCID: PMCPMC7094566.

89. Chen J, Jiang Q, Xia X, Liu K, Yu Z, Tao W, et al. Individual variation of the SARS-CoV-2 receptor ACE2 gene expression and regulation. Aging Cell. 2020;19(7). Epub 2020/06/20. https:// doi.org/10.1111/acel.13168. PubMed PMID: 32558150; PubMed Central PMCID: PMCPMC7323071.

90. Lieb W, Graf J, Gotz A, Konig IR, Mayer B, Fischer M, et al. Association of angiotensin-converting enzyme 2 (ACE2) gene polymorphisms with parameters of left ventricular hypertrophy in men. Results of the MONICA Augsburg echocardiographic substudy. J Mol Med (Berl). 2006;84(1):88-96. Epub 2005/11/12. https://doi.org/10.1007/s00109-005-0718-5. PubMed PMID: 16283142.

91. Singh H, Choudhari R, Nema V, Khan AA. ACE2 and TMPRSS2 polymorphisms in various diseases with special reference to its impact on COVID-19 disease. Microb Pathog. 2021;150:104621. Epub 2020/12/06. https://doi.org/10.1016/j.micpath.2020. 104621. PubMed PMID: 33278516; PubMed Central PMCID: PMCPMC7709597.

92. Vom Steeg LG, Klein SL. Sex and sex steroids impact influenza pathogenesis across the life course. Semin Immunopathol. 2019;41(2):189-94. Epub 2018/10/10. https://doi.org/10.1007/ s00281-018-0718-5. PubMed PMID: 30298431; PubMed Central PMCID: PMCPMC6370518.

93. Karlberg J, Chong DS, Lai WY. Do men have a higher case fatality rate of severe acute respiratory syndrome than women do? Am J Epidemiol. 2004;159(3):229-31. Epub 2004/01/27. https:// doi.org/10.1093/aje/kwh056. PubMed PMID: 14742282; PubMed Central PMCID: PMCPMC7110237.

94. Matsuyama R, Nishiura H, Kutsuna S, Hayakawa K, Ohmagari N. Clinical determinants of the severity of Middle East respiratory syndrome (MERS): a systematic review and meta-analysis. BMC Public Health. 2016;16(1):1203. Epub 2016/12/03. https:// doi.org/10.1186/s12889-016-3881-4. PubMed PMID: 27899100; PubMed Central PMCID: PMCPMC5129628.

95. Ortolan A, Lorenzin M, Felicetti M, Doria A, Ramonda R. Does gender influence clinical expression and disease outcomes in 
COVID-19? A systematic review and meta-analysis. Int J Infect Dis. 2020;99:496-504. Epub 2020/08/18. https://doi.org/10. 1016/j.ijid.2020.07.076. PubMed PMID: 32800858; PubMed Central PMCID: PMCPMC7422797.

96. Peckham H, de Gruijter NM, Raine C, Radziszewska A, Ciurtin $\mathrm{C}$, Wedderburn LR, et al. Male sex identified by global COVID19 meta-analysis as a risk factor for death and ITU admission. Nat Commun. 2020;11(1):6317. Epub 2020/12/11. https://doi. org/10.1038/s41467-020-19741-6. PubMed PMID: 33298944; PubMed Central PMCID: PMCPMC7726563.

97. Agrawal H, Das N, Nathani S, Saha S, Saini S, Kakar SS, et al. An Assessment on Impact of COVID-19 Infection in a Gender Specific Manner. Stem Cell Rev Rep. 2020. Epub 2020/10/09. https://doi.org/10.1007/s12015-020-10048-z. PubMed PMID: 33029768; PubMed Central PMCID: PMCPMC7541100.

98. Qian J, Zhao L, Ye RZ, Li XJ, Liu YL. Age-dependent Gender Differences in COVID-19 in Mainland China: Comparative Study. Clin Infect Dis. 2020;71(9):2488-94. Epub 2020/05/31. https://doi.org/10.1093/cid/ciaa683. PubMed PMID: 32473009; PubMed Central PMCID: PMCPMC7314154.

99. Cagnacci A, Xholli A. Change in Covid-19 infection and mortality rates in postmenopausal women. Menopause. 2021;Publish Ahead of Print. Epub 2021/01/14. https://doi.org/10.1097/GME. 0000000000001731. PubMed PMID: 33438894.

100. Scully EP, Haverfield J, Ursin RL, Tannenbaum C, Klein SL. Considering how biological sex impacts immune responses and COVID-19 outcomes. Nat Rev Immunol. 2020;20(7):442-7. Epub 2020/06/13. https://doi.org/10.1038/s41577-020-0348-8. PubMed PMID: 32528136; PubMed Central PMCID: PMCPMC7288618.

101. Mauvais-Jarvis F, Bairey Merz N, Barnes PJ, Brinton RD, Carrero JJ, DeMeo DL, et al. Sex and gender: modifiers of health, disease, and medicine. Lancet. 2020;396(10250):565-82. Epub 2020/08/24. https://doi.org/10.1016/S0140-6736(20)315610. PubMed PMID: 32828189; PubMed Central PMCID: PMCPMC7440877.

102. Haischer MH, Beilfuss R, Hart MR, Opielinski L, Wrucke D, Zirgaitis G, et al. Who is wearing a mask? Gender-, age-, and location-related differences during the COVID-19 pandemic. PLoS One. 2020;15(10):e0240785. Epub 2020/10/16. https://doi. org/10.1371/journal.pone.0240785. PubMed PMID: 33057375; PubMed Central PMCID: PMCPMC7561164.

103. Klein SL, Flanagan KL. Sex differences in immune responses. Nat Rev Immunol. 2016;16(10):626-38. Epub 2016/08/23. https://doi.org/10.1038/nri.2016.90. PubMed PMID: 27546235.

104. Stelzer IA, Arck PA. Immunity and the Endocrine System In: Ratcliffe MJH, editor. Encyclopedia of Immunobiology: Academic Press; 2016. p. 73-85.

105. Takahashi T, Ellingson MK, Wong P, Israelow B, Lucas C, Klein J, et al. Sex differences in immune responses that underlie COVID-19 disease outcomes. Nature. 2020. Epub 2020/08/28. https://doi.org/10.1038/s41586-020-2700-3. PubMed PMID: 32846427.

106. Del Valle DM, Kim-Schulze S, Huang HH, Beckmann ND, Nirenberg S, Wang B, et al. An inflammatory cytokine signature predicts COVID-19 severity and survival. Nat Med. 2020;26(10):1636-43. Epub 2020/08/26. https://doi.org/10.1038/ s41591-020-1051-9. PubMed PMID: 32839624

107. Luo M, Liu J, Jiang W, Yue S, Liu H, Wei S. IL-6 and CD8+ T cell counts combined are an early predictor of in-hospital mortality of patients with COVID-19. JCI Insight. 2020;5(13). Epub 2020/06/17. https://doi.org/10.1172/jci.insight.139024. PubMed PMID: 32544099; PubMed Central PMCID: PMCPMC7406244.

108. Chen Z, John Wherry E. T cell responses in patients with COVID19. Nat Rev Immunol. 2020;20(9):529-36. Epub 2020/07/31. https://doi.org/10.1038/s41577-020-0402-6. PubMed PMID: 32728222; PubMed Central PMCID: PMCPMC7389156.
109. Giefing-Kröll C, Berger P, Lepperdinger G, Grubeck-Loebenstein B. How sex and age affect immune responses, susceptibility to infections, and response to vaccination. Aging Cell. 2015;14(3):309-21 (PubMed PMID: 25720438).

110. vom Steeg LG, Klein SL. SeXX Matters in Infectious Disease Pathogenesis. PLoS Pathog. 2016;12(2):e1005374. Epub 2016/02/20. https://doi.org/10.1371/journal.ppat.1005374. PubMed PMID: 26891052; PubMed Central PMCID: PMCPMC4759457.

111. Klein SL, Hodgson A, Robinson DP. Mechanisms of sex disparities in influenza pathogenesis. J Leukoc Biol. 2012;92(1):67-73. Epub 2011/12/02. https://doi.org/10.1189/jlb.0811427. PubMed PMID: 22131346; PubMed Central PMCID: PMCPMC4046247.

112. Weksler ME, Szabo P. The effect of age on the B-cell repertoire. J Clin Immunol. 2000;20(4):240-9. Epub 2000/08/12. https:// doi.org/10.1023/a:1006659401385. PubMed PMID: 10939711.

113. Fink AL, Klein SL. Sex and Gender Impact Immune Responses to Vaccines Among the Elderly. Physiology (Bethesda). 2015;30(6):408-16. Epub 2015/11/04. https://doi.org/10.1152/ physiol.00035.2015. PubMed PMID: 26525340; PubMed Central PMCID: PMCPMC4630198.

114. Zeng F, Dai C, Cai P, Wang J, Xu L, Li J, et al. A comparison study of SARS-CoV-2 IgG antibody between male and female COVID-19 patients: A possible reason underlying different outcome between sex. J Med Virol. 2020. Epub 2020/05/10. https:// doi.org/10.1002/jmv.25989. PubMed PMID: 32383183; PubMed Central PMCID: PMCPMC7267228.

115. Vural P, Akgul C, Canbaz M. Effects of hormone replacement therapy on plasma pro-inflammatory and anti-inflammatory cytokines and some bone turnover markers in postmenopausal women. Pharmacol Res. 2006;54(4):298-302. Epub 2006/08/02. https://doi.org/10.1016/j.phrs.2006.06.006. PubMed PMID: 16879975.

116. Scheidt-Nave C, Bismar H, Leidig-Bruckner G, Woitge H, Seibel MJ, Ziegler R, et al. Serum interleukin 6 is a major predictor of bone loss in women specific to the first decade past menopause. J Clin Endocrinol Metab. 2001;86(5):2032-42. Epub 2001/05/10. https://doi.org/10.1210/jcem.86.5.7445. PubMed PMID: 11344203.

117. Straub RH, Hense HW, Andus T, Scholmerich J, Riegger GA, Schunkert H. Hormone replacement therapy and interrelation between serum interleukin- 6 and body mass index in postmenopausal women: a population-based study. J Clin Endocrinol Metab. 2000;85(3):1340-4. Epub 2000/03/17. https://doi.org/ 10.1210/jcem.85.3.6355. PubMed PMID: 10720088.

118. Rachon D, Mysliwska J, Suchecka-Rachon K, Wieckiewicz J, Mysliwski A. Effects of oestrogen deprivation on interleukin-6 production by peripheral blood mononuclear cells of postmenopausal women. J Endocrinol. 2002;172(2):387-95. Epub 2002/02/09. https://doi.org/10.1677/joe.0.1720387. PubMed PMID: 11834456.

119. Seeland U, Coluzzi F, Simmaco M, Mura C, Bourne PE, Heiland $\mathrm{M}$, et al. Evidence for treatment with estradiol for women with SARS-CoV-2 infection. BMC Med. 2020;18(1):369. Epub 2020/11/26. https://doi.org/10.1186/s12916-020-01851z. PubMed PMID: 33234138; PubMed Central PMCID: PMCPMC7685778.

120. Ding T, Zhang J, Wang T, Cui P, Chen Z, Jiang J, et al. Potential Influence of Menstrual Status and Sex Hormones on female SARS-CoV-2 Infection: A Cross-sectional Study from Multicentre in Wuhan, China. Clin Infect Dis. 2020. Epub 2020/07/23. https://doi.org/10.1093/cid/ciaa1022. PubMed PMID: 32697835; PubMed Central PMCID: PMCPMC7454316.

121. Iba T, Levy JH, Levi M, Thachil J. Coagulopathy in COVID-19. J Thromb Haemost. 2020. Epub 2020/06/20. https://doi.org/10. 1111/jth.14975. PubMed PMID: 32558075. 
122. Cagnacci A, Bonaccorsi G, Gambacciani M, board of the Italian Menopause S. Reflections and recommendations on the COVID19 pandemic: Should hormone therapy be discontinued? Maturitas. 2020;138:76-7. Epub 2020/06/23. https://doi.org/10.1016/j. maturitas.2020.05.022. PubMed PMID: 32565009; PubMed Central PMCID: PMCPMC7301099.

123. Harman SM, Metter EJ, Tobin JD, Pearson J, Blackman MR, Baltimore Longitudinal Study of A. Longitudinal effects of aging on serum total and free testosterone levels in healthy men. Baltimore Longitudinal Study of Aging. J Clin Endocrinol Metab. 2001;86(2):724-31. Epub 2001/02/07. https://doi.org/10.1210/ jcem.86.2.7219. PubMed PMID: 11158037.

124. Montopoli M, Zumerle S, Vettor R, Rugge M, Zorzi M, Catapano $\mathrm{CV}$, et al. Androgen-deprivation therapies for prostate cancer and risk of infection by SARS-CoV-2: a population-based study ( $\mathrm{N}=4532$ ). Ann Oncol. 2020;31(8):1040-5. Epub 2020/05/11. https://doi.org/10.1016/j.annonc.2020.04.479. PubMed PMID: 32387456; PubMed Central PMCID: PMCPMC7202813.

125. Lazzeri M, Duga S, Azzolini E, Fasulo V, Buffi N, Saita A, et al. Impact of chronic exposure to 5-alpha reductase inhibitors on the risk of hospitalization for COVID-19: a case-control study in male population from two COVID-19 regional centers of Lombardy (Italy). Minerva Urol Nefrol. 2021. Epub 2021/01/14. https://doi.org/10.23736/S0393-2249.20.04081-3. PubMed PMID: 33439572.

126. Cattrini C, Bersanelli M, Latocca MM, Conte B, Vallome G, Boccardo F. Sex Hormones and Hormone Therapy during COVID-19 Pandemic: Implications for Patients with Cancer. Cancers (Basel). 2020;12(8). Epub 2020/08/23. https://doi.org/ 10.3390/cancers 12082325. PubMed PMID: 32824674; PubMed Central PMCID: PMCPMC7464909.

127. Rastrelli G, Carter EL, Ahern T, Finn JD, Antonio L, O'Neill TW, et al. Development of and Recovery from Secondary Hypogonadism in Aging Men: Prospective Results from the EMAS. J Clin Endocrinol Metab. 2015;100(8):3172-82. Epub 2015/05/23. https://doi.org/10.1210/jc.2015-1571. PubMed PMID: 26000545.

128. Rastrelli G, Di Stasi V, Inglese F, Beccaria M, Garuti M, Di Costanzo D, et al. Low testosterone levels predict clinical adverse outcomes in SARS-CoV-2 pneumonia patients. Andrology. 2021;9(1):88-98. Epub 2020/05/22. https://doi.org/10.1111/andr. 12821. PubMed PMID: 32436355; PubMed Central PMCID: PMCPMC7280645.

129. Çayan S, Uğuz M, Saylam B, Akbay E. Effect of serum total testosterone and its relationship with other laboratory parameters on the prognosis of coronavirus disease 2019 (COVID-19) in SARS-CoV-2 infected male patients: a cohort study. Aging Male. 2020:1-11. Epub 2020/09/05. https://doi.org/10.1080/13685538. 2020.1807930. PubMed PMID: 32883151

130. Wang Y, Chen L, Xie L, Li L, Li X, Li H, et al. Interleukin 6 inhibits the differentiation of rat stem Leydig cells. Mol Cell Endocrinol. 2018;472:26-39. Epub 2017/11/29. https://doi.org/ 10.1016/j.mce.2017.11.016. PubMed PMID: 29180110.

131. Kalinchenko SY, Tishova YA, Mskhalaya GJ, Gooren LJ, Giltay EJ, Saad F. Effects of testosterone supplementation on markers of the metabolic syndrome and inflammation in hypogonadal men with the metabolic syndrome: the double-blinded placebo-controlled Moscow study. Clin Endocrinol (Oxf). 2010;73(5):602-12. Epub 2010/08/20. https://doi.org/10.1111/j.1365-2265.2010. 03845.x. PubMed PMID: 20718771.

132. Malkin CJ, Pugh PJ, Jones RD, Kapoor D, Channer KS, Jones TH. The effect of testosterone replacement on endogenous inflammatory cytokines and lipid profiles in hypogonadal men. J Clin Endocrinol Metab. 2004;89(7):3313-8. Epub 2004/07/09. https:// doi.org/10.1210/jc.2003-031069. PubMed PMID: 15240608.

133. Maggio M, Snyder PJ, De Vita F, Ceda GP, Milaneschi Y, Lauretani F, et al. Effects of transdermal testosterone treatment on inflammatory markers in elderly males. Endocr Pract. 2014;20(11):1170-7. Epub 2014/08/08. https://doi.org/10. 4158/EP13357.OR. PubMed PMID: 25100359; PubMed Central PMCID: PMCPMC5012420.

134. Sun M, Shankar R, Ko M, Chang CD, Yeh SJ, Li S, et al. Sex differences in viral entry protein expression, host responses to SARS-CoV-2, and in vitro responses to sex steroid hormone treatment in COVID-19. Res Sq. 2020. Epub 2020/11/12. https:// doi.org/10.21203/rs.3.rs-100914/v1. PubMed PMID: 33173861; PubMed Central PMCID: PMCPMC7654875.

135. Villareal DT, Apovian CM, Kushner RF, Klein S, American Society for N, Naaso TOS. Obesity in older adults: technical review and position statement of the American Society for Nutrition and NAASO, The Obesity Society. Am J Clin Nutr. 2005;82(5):923-34. Epub 2005/11/11. https://doi.org/10.1093/ ajcn/82.5.923. PubMed PMID: 16280421.

136. Donini LM, Busetto L, Bauer JM, Bischoff S, Boirie Y, Cederholm $\mathrm{T}$, et al. Critical appraisal of definitions and diagnostic criteria for sarcopenic obesity based on a systematic review. Clin Nutr. 2020;39(8):2368-88. Epub 2019/12/10. https://doi.org/10.1016/j. clnu.2019.11.024. PubMed PMID: 31813698.

137. Toogood AA. Growth hormone (GH) status and body composition in normal ageing and in elderly adults with GH deficiency. Horm Res. 2003;60(Suppl 1):105-11. Epub 2003/09/05. https:// doi.org/10.1159/000071234. PubMed PMID: 12955026.

138. Ambikairajah A, Walsh E, Tabatabaei-Jafari H, Cherbuin N. Fat mass changes during menopause: a metaanalysis. Am J Obstet Gynecol. 2019;221(5):393-409 e50. Epub 2019/04/30. https:// doi.org/10.1016/j.ajog.2019.04.023. PubMed PMID: 31034807.

139. Finkelstein JS, Lee H, Burnett-Bowie SA, Pallais JC, Yu EW, Borges LF, et al. Gonadal steroids and body composition, strength, and sexual function in men. N Engl J Med. 2013;369(11):1011-22. Epub 2013/09/13. https://doi.org/10.1056/NEJMoa1206168. PubMed PMID: 24024838; PubMed Central PMCID: PMCPMC4142768.

140. Azzolino D, Cesari M. Obesity and COVID-19. Front Endocrinol (Lausanne). 2020;11:581356. Epub 2020/10/27. https://doi.org/ 10.3389/fendo.2020.581356. PubMed PMID: 33101213; PubMed Central PMCID: PMCPMC7554630.

141. Wang PY, Li Y, Wang Q. Sarcopenia: An underlying treatment target during the COVID-19 pandemic. Nutrition. 2020;84:111104. Epub 2021/01/10. https://doi.org/10.1016/j.nut.2020.111104. PubMed PMID: 33421827; PubMed Central PMCID: PMCPMC7833321.

142. Cruz-Jentoft AJ, Bahat G, Bauer J, Boirie Y, Bruyere O, Cederholm T, et al. Sarcopenia: revised European consensus on definition and diagnosis. Age Ageing. 2019;48(1):16-31. Epub 2018/10/13. https://doi.org/10.1093/ageing/afy169. PubMed PMID: 30312372; PubMed Central PMCID: PMCPMC6322506.

143. Mayhew AJ, Amog K, Phillips S, Parise G, McNicholas PD, de Souza RJ, et al. The prevalence of sarcopenia in communitydwelling older adults, an exploration of differences between studies and within definitions: a systematic review and meta-analyses. Age Ageing. 2019;48(1):48-56. Epub 2018/07/28. https://doi. org/10.1093/ageing/afy106. PubMed PMID: 30052707.

144. Bahat G, Tufan A, Ozkaya H, Tufan F, Akpinar TS, Akin S, et al. Relation between hand grip strength, respiratory muscle strength and spirometric measures in male nursing home residents. Aging Male. 2014;17(3):136-40. Epub 2014/07/06. https://doi.org/10. 3109/13685538.2014.936001. PubMed PMID: 24993454.

145. Altuna-Venegas S, Aliaga-Vega R, Maguina JL, Parodi JF, Runzer-Colmenares FM. Risk of community-acquired pneumonia in older adults with sarcopenia of a hospital from Callao, Peru 2010-2015. Arch Gerontol Geriatr. 2019;82:100-5. Epub 2019/02/11. https://doi.org/10.1016/j.archger.2019.01.008. PubMed PMID: 30739000. 
146. Moisey LL, Mourtzakis M, Cotton BA, Premji T, Heyland DK, Wade CE, et al. Skeletal muscle predicts ventilator-free days, ICU-free days, and mortality in elderly ICU patients. Crit Care. 2013;17(5):R206. Epub 2013/09/21. https://doi.org/10.1186/ cc12901. PubMed PMID: 24050662; PubMed Central PMCID: PMCPMC4055977.

147. Gariballa S, Alessa A. Sarcopenia: prevalence and prognostic significance in hospitalized patients. Clin Nutr. 2013;32(5):7726. Epub 2013/02/12. https://doi.org/10.1016/j.clnu.2013.01.010. PubMed PMID: 23395102.

148. Bianchi L, Maietti E, Abete P, Bellelli G, Bo M, Cherubini A, et al. Comparing EWGSOP2 and FNIH Sarcopenia Definitions: Agreement and 3-Year Survival Prognostic Value in Older Hospitalized Adults: The GLISTEN Study. J Gerontol A Biol Sci Med Sci. 2020;75(7):1331-7. Epub 2019/10/20. https://doi. org/10.1093/gerona/glz249. PubMed PMID: 31628464.

149. Martone AM, Bianchi L, Abete P, Bellelli G, Bo M, Cherubini A, et al. The incidence of sarcopenia among hospitalized older patients: results from the Glisten study. J Cachexia Sarcopenia Muscle. 2017;8(6):907-14. Epub 2017/09/16. https://doi. org/10.1002/jcsm.12224. PubMed PMID: 28913934; PubMed Central PMCID: PMCPMC5700449.

150. Rommersbach N, Wirth R, Lueg G, Klimek C, Schnatmann M, Liermann $\mathrm{D}$, et al. The impact of disease-related immobilization on thigh muscle mass and strength in older hospitalized patients. BMC Geriatr. 2020;20(1):500. Epub 2020/11/27. https://doi.org/10.1186/s12877-020-01873-5. PubMed PMID: 33238889; PubMed Central PMCID: PMCPMC7687989.

151. Kortebein P, Ferrando A, Lombeida J, Wolfe R, Evans WJ. Effect of 10 days of bed rest on skeletal muscle in healthy older adults. JAMA. 2007;297(16):1772-4. Epub 2007/04/26. https://doi.org/ 10.1001/jama.297.16.1772-b. PubMed PMID: 17456818.

152. Morley JE, Kalantar-Zadeh K, Anker SD. COVID-19: a major cause of cachexia and sarcopenia? J Cachexia Sarcopenia Muscle. 2020;11(4):863-5. Epub 2020/06/11. https://doi.org/10. 1002/jcsm.12589. PubMed PMID: 32519505; PubMed Central PMCID: PMCPMC7300782.

153. Gemelli Against C-P-ACSG. Post-COVID-19 global health strategies: the need for an interdisciplinary approach. Aging Clin Exp Res. 2020;32(8):1613-20. Epub 2020/06/13. https://doi.org/10. 1007/s40520-020-01616-x. PubMed PMID: 32529595; PubMed Central PMCID: PMCPMC7287410.

154. Ufuk F, Demirci M, Sagtas E, Akbudak IH, Ugurlu E, Sari T. The prognostic value of pneumonia severity score and pectoralis muscle Area on chest CT in adult COVID-19 patients. Eur J Radiol. 2020;131:109271. Epub 2020/09/18. https://doi.org/10. 1016/j.ejrad.2020.109271. PubMed PMID: 32942198; PubMed Central PMCID: PMCPMC7480333.

155. Ammar A, Brach M, Trabelsi K, Chtourou H, Boukhris O, Masmoudi L, et al. Effects of COVID-19 Home Confinement on Eating Behaviour and Physical Activity: Results of the ECLBCOVID19 International Online Survey. Nutrients. 2020;12(6). Epub 2020/06/03. https://doi.org/10.3390/nu12061583. PubMed PMID: 32481594; PubMed Central PMCID: PMCPMC7352706.

156. Lopez-Moreno M, Lopez MTI, Miguel M, Garces-Rimon M. Physical and Psychological Effects Related to Food Habits and Lifestyle Changes Derived from Covid-19 Home Confinement in the Spanish Population. Nutrients. 2020;12(11). Epub 2020/11/14. https://doi.org/10.3390/nu12113445. PubMed PMID: 33182816; PubMed Central PMCID: PMCPMC7696994.

157. McGlory C, von Allmen MT, Stokes T, Morton RW, Hector AJ, Lago BA, et al. Failed Recovery of Glycemic Control and Myofibrillar Protein Synthesis With 2 wk of Physical Inactivity in Overweight, Prediabetic Older Adults. J Gerontol A Biol Sci Med Sci. 2018;73(8):1070-7. Epub 2017/11/03. https://doi.org/ 10.1093/gerona/glx203. PubMed PMID: 29095970; PubMed Central PMCID: PMCPMC6037059.

158. Breen L, Stokes KA, Churchward-Venne TA, Moore DR, Baker SK, Smith K, et al. Two weeks of reduced activity decreases leg lean mass and induces "anabolic resistance" of myofibrillar protein synthesis in healthy elderly. J Clin Endocrinol Metab. 2013;98(6):2604-12. Epub 2013/04/17. https://doi.org/10.1210/ jc.2013-1502. PubMed PMID: 23589526.

159. Wohleb ES, Franklin T, Iwata M, Duman RS. Integrating neuroimmune systems in the neurobiology of depression. Nat Rev Neurosci. 2016;17(8):497-511. Epub 2016/06/10. https://doi.org/ 10.1038/nrn.2016.69. PubMed PMID: 27277867.

160. Morris MJ, Beilharz JE, Maniam J, Reichelt AC, Westbrook RF. Why is obesity such a problem in the 21 st century? The intersection of palatable food, cues and reward pathways, stress, and cognition. Neurosci Biobehav Rev. 2015;58:36-45. Epub 2014/12/17. https://doi.org/10.1016/j.neubiorev.2014.12.002. PubMed PMID: 25496905.

161. Dalle S, Rossmeislova L, Koppo K. The Role of Inflammation in Age-Related Sarcopenia. Front Physiol. 2017;8:1045. Epub 2018/01/10. https://doi.org/10.3389/fphys.2017.01045. PubMed PMID: 29311975; PubMed Central PMCID: PMCPMC5733049.

162. Li X, Moody MR, Engel D, Walker S, Clubb FJ, Jr., Sivasubramanian $\mathrm{N}$, et al. Cardiac-specific overexpression of tumor necrosis factoralpha causes oxidative stress and contractile dysfunction in mouse diaphragm. Circulation. 2000;102(14):1690-6. Epub 2000/10/04. https:// doi.org/10.1161/01.cir.102.14.1690. PubMed PMID: 11015349.

163. Welch C, Z KH-S, C AG, J ML, T AJ. Acute Sarcopenia Secondary to Hospitalisation - An Emerging Condition Affecting Older Adults. Aging Dis. 2018;9(1):151-64. Epub 2018/02/03. https:// doi.org/10.14336/AD.2017.0315. PubMed PMID: 29392090; PubMed Central PMCID: PMCPMC5772853.

164. Newman AB, Lee JS, Visser M, Goodpaster BH, Kritchevsky SB, Tylavsky FA, et al. Weight change and the conservation of lean mass in old age: the Health, Aging and Body Composition Study. Am J Clin Nutr. 2005;82(4):872-8; quiz 915-6. Epub 2005/10/08. https://doi.org/10.1093/ajen/82.4.872. PubMed PMID: 16210719.

165. Sheean PM, Peterson SJ, Gomez Perez S, Troy KL, Patel A, Sclamberg JS, et al. The prevalence of sarcopenia in patients with respiratory failure classified as normally nourished using computed tomography and subjective global assessment. JPEN J Parenter Enteral Nutr. 2014;38(7):873-9. Epub 2013/08/28. https://doi.org/10.1177/0148607113500308. PubMed PMID: 23980135; PubMed Central PMCID: PMCPMC3935982.

166. Tajar A, Huhtaniemi IT, O'Neill TW, Finn JD, Pye SR, Lee $\mathrm{DM}$, et al. Characteristics of androgen deficiency in late-onset hypogonadism: results from the European Male Aging Study (EMAS). J Clin Endocrinol Metab. 2012;97(5):1508-16. Epub 2012/03/16. https://doi.org/10.1210/jc.2011-2513. PubMed PMID: 22419720.

167. Antonio L, Wu FC, O'Neill TW, Pye SR, Carter EL, Finn $\mathrm{JD}$, et al. Associations between sex steroids and the development of metabolic syndrome: a longitudinal study in European men. J Clin Endocrinol Metab. 2015;100(4):1396-404. Epub 2015/01/31. https://doi.org/10.1210/jc.2014-4184. PubMed PMID: 25636052.

168. Laughlin GA, Barrett-Connor E, Bergstrom J. Low serum testosterone and mortality in older men. J Clin Endocrinol Metab. 2008;93(1):68-75. Epub 2007/10/04. https://doi.org/10.1210/ jc.2007-1792. PubMed PMID: 17911176; PubMed Central PMCID: PMCPMC2190742.

169. Wu FC, Tajar A, Pye SR, Silman AJ, Finn JD, O'Neill TW, et al. Hypothalamic-pituitary-testicular axis disruptions in older men are differentially linked to age and modifiable risk factors: 
the European Male Aging Study. J Clin Endocrinol Metab. 2008;93(7):2737-45. Epub 2008/02/14. https://doi.org/10.1210/ jc.2007-1972. PubMed PMID: 18270261.

170. Camacho EM, Huhtaniemi IT, O'Neill TW, Finn JD, Pye SR, Lee DM, et al. Age-associated changes in hypothalamicpituitary-testicular function in middle-aged and older men are modified by weight change and lifestyle factors: longitudinal results from the European Male Ageing Study. Eur J Endocrinol. 2013;168(3):445-55. Epub 2013/02/22. https://doi.org/ 10.1530/EJE-12-0890. PubMed PMID: 23425925.

171. Salciccia S, Del Giudice F, Gentile V, Mastroianni CM, Pasculli P, Di Lascio G, et al. Interplay between male testosterone levels and the risk for subsequent invasive respiratory assistance among COVID-19 patients at hospital admission. Endocrine. 2020;70(2):206-10. Epub 2020/10/09. https://doi. org/10.1007/s12020-020-02515-x. PubMed PMID: 33030665; PubMed Central PMCID: PMCPMC7543668.

172. You T, Ryan AS, Nicklas BJ. The metabolic syndrome in obese postmenopausal women: relationship to body composition, visceral fat, and inflammation. J Clin Endocrinol Metab. 2004;89(11):5517-22. Epub 2004/10/19. https://doi.org/10. 1210/jc.2004-0480. PubMed PMID: 15489217.

173. Ofori EK, Conde Alonso S, Correas-Gomez L, Carnero EA, Zwygart K, Hugues $\mathrm{H}$, et al. Thigh and abdominal adipose tissue depot associations with testosterone levels in postmenopausal females. Clin Endocrinol (Oxf). 2019;90(3):433-9. Epub 2018/12/24. https://doi.org/10.1111/cen.13921. PubMed PMID: 30575083.

174. Meun C, Franco OH, Dhana K, Jaspers L, Muka T, Louwers Y, et al. High Androgens in Postmenopausal Women and the Risk for Atherosclerosis and Cardiovascular Disease: The Rotterdam Study. J Clin Endocrinol Metab. 2018;103(4):1622-30. Epub 2018/02/07. https://doi.org/10.1210/jc.2017-02421. PubMed PMID: 29408955.

175. Patel SM, Ratcliffe SJ, Reilly MP, Weinstein R, Bhasin S, Blackman MR, et al. Higher serum testosterone concentration in older women is associated with insulin resistance, metabolic syndrome, and cardiovascular disease. J Clin Endocrinol Metab. 2009;94(12):4776-84. Epub 2009/10/23. https://doi. org/10.1210/jc.2009-0740. PubMed PMID: 19846742; PubMed Central PMCID: PMCPMC2795656.

176. Bochud M, Ponte B, Pruijm M, Ackermann D, Guessous I, Ehret G, et al. Urinary Sex Steroid and Glucocorticoid Hormones Are Associated With Muscle Mass and Strength in Healthy Adults. J Clin Endocrinol Metab. 2019;104(6):2195215. Epub 2019/01/29. https://doi.org/10.1210/jc.2018-01942. PubMed PMID: 30690465.

177. Heaney JL, Phillips AC, Carroll D. Ageing, physical function, and the diurnal rhythms of cortisol and dehydroepiandrosterone. Psychoneuroendocrinology. 2012;37(3):341-9. Epub 2011/08/02. https://doi.org/10.1016/j.psyneuen.2011.07.001. PubMed PMID: 21802858.

178. Nair KS, Rizza RA, O'Brien P, Dhatariya K, Short KR, Nehra A, et al. DHEA in elderly women and DHEA or testosterone in elderly men. N Engl J Med. 2006;355(16):1647-59. Epub 2006/10/20. https://doi.org/10.1056/NEJMoa054629. PubMed PMID: 17050889.

179. Nakamura S, Mizuno M, Katakami H, Gore AC, Terasawa E. Aging-related changes in in vivo release of growth hormonereleasing hormone and somatostatin from the stalk-median eminence in female rhesus monkeys (Macaca mulatta). J Clin Endocrinol Metab. 2003;88(2):827-33. Epub 2003/02/08. https://doi. org/10.1210/jc.2002-021568. PubMed PMID: 12574220.

180. Steyn FJ, Tolle V, Chen C, Epelbaum J. Neuroendocrine Regulation of Growth Hormone Secretion. Compr Physiol.
2016;6(2):687-735. Epub 2016/04/12. https://doi.org/10.1002/ cphy.c150002. PubMed PMID: 27065166.

181. Bodart G, Goffinet L, Morrhaye G, Farhat K, de Saint-Hubert M, Debacq-Chainiaux F, et al. Somatotrope GHRH/GH/IGF-1 axis at the crossroads between immunosenescence and frailty. Ann N Y Acad Sci. 2015;1351:61-7. Epub 2015/08/19. https:// doi.org/10.1111/nyas.12857. PubMed PMID: 26284958.

182. Yin Y, Zhang W. The Role of Ghrelin in Senescence: A MiniReview. Gerontology. 2016;62(2):155-62. Epub 2015/07/15. https://doi.org/10.1159/000433533. PubMed PMID: 26160147.

183. Moffat SD, An Y, Resnick SM, Diamond MP, Ferrucci L. Longitudinal Change in Cortisol Levels Across the Adult Life Span. J Gerontol A Biol Sci Med Sci. 2020;75(2):394-400. Epub 2019/11/13. https://doi.org/10.1093/gerona/gly279. PubMed PMID: 31714574; PubMed Central PMCID: PMCPMC7176109.

184. Peeters GM, van Schoor NM, van Rossum EF, Visser M, Lips $\mathrm{P}$. The relationship between cortisol, muscle mass and muscle strength in older persons and the role of genetic variations in the glucocorticoid receptor. Clin Endocrinol (Oxf). 2008;69(4):67382. Epub 2008/02/06. https://doi.org/10.1111/j.1365-2265.2008. 03212.x. PubMed PMID: 18248637.

185. Escher G, Galli I, Vishwanath BS, Frey BM, Frey FJ. Tumor necrosis factor alpha and interleukin 1beta enhance the cortisone/cortisol shuttle. J Exp Med. 1997;186(2):189-98. Epub 1997/07/21. https://doi.org/10.1084/jem.186.2.189. PubMed PMID: 9221748; PubMed Central PMCID: PMCPMC2198986.

186. Kilgour AH, Gallagher IJ, MacLullich AM, Andrew R, Gray CD, Hyde P, et al. Increased skeletal muscle 11betaHSD1 mRNA is associated with lower muscle strength in ageing. PLoS One. 2013;8(12):e84057. Epub 2014/01/07. https://doi.org/10.1371/ journal.pone.0084057. PubMed PMID: 24391882; PubMed Central PMCID: PMCPMC3877148.

187. Morton NM, Paterson JM, Masuzaki H, Holmes MC, Staels B, Fievet $\mathrm{C}$, et al. Novel adipose tissue-mediated resistance to diet-induced visceral obesity in 11 beta-hydroxysteroid dehydrogenase type 1-deficient mice. Diabetes. 2004;53(4):931-8. Epub 2004/03/30. https://doi.org/ 10.2337/diabetes.53.4.931. PubMed PMID: 15047607.

188. Battisti S, Pedone C, Napoli N, Russo E, Agnoletti V, Nigra SG, et al. Computed Tomography Highlights Increased Visceral Adiposity Associated With Critical Illness in COVID-19. Diabetes Care. 2020;43(10):e129-e30. Epub 2020/08/06. https://doi.org/ 10.2337/dc20-1333. PubMed PMID: 32753457.

189. Petersen A, Bressem K, Albrecht J, Thiess HM, Vahldiek J, Hamm $\mathrm{B}$, et al. The role of visceral adiposity in the severity of COVID19: Highlights from a unicenter cross-sectional pilot study in Germany. Metabolism. 2020;110:154317. Epub 2020/07/17. https://doi.org/10.1016/j.metabol.2020.154317. PubMed PMID: 32673651; PubMed Central PMCID: PMCPMC7358176.

190. Watanabe M, Caruso D, Tuccinardi D, Risi R, Zerunian M, Polici $\mathrm{M}$, et al. Visceral fat shows the strongest association with the need of intensive care in patients with COVID-19. Metabolism. 2020;111:154319. Epub 2020/07/28. https://doi.org/10.1016/j. metabol.2020.154319. PubMed PMID: 32712222; PubMed Central PMCID: PMCPMC7377788.

191. Yang Y, Ding L, Zou X, Shen Y, Hu D, Hu X, et al. Visceral Adiposity and High Intramuscular Fat Deposition Independently Predict Critical Illness in Patients with SARS-CoV-2. Obesity (Silver Spring). 2020;28(11):2040-8. Epub 2020/07/18. https:// doi.org/10.1002/oby.22971. PubMed PMID: 32677752; PubMed Central PMCID: PMCPMC7405187.

192. Favre G, Legueult K, Pradier C, Raffaelli C, Ichai C, Iannelli A, et al. Visceral fat is associated to the severity of COVID-19. Metabolism. 2021;115:154440. Epub 2020/11/28. https://doi. org/10.1016/j.metabol.2020.154440. PubMed PMID: 33246009; PubMed Central PMCID: PMCPMC7685947. 
193. Pediconi F, Rizzo V, Schiaffino S, Cozzi A, Della Pepa G, Galati F, et al. Visceral adipose tissue area predicts intensive care unit admission in COVID-19 patients. Obes Res Clin Pract. 2021;15(1):89-92. Epub 2020/12/29. https://doi.org/10.1016/j. orcp.2020.12.002. PubMed PMID: 33358147; PubMed Central PMCID: PMCPMC7836243.

194. Smith SR, Lovejoy JC, Greenway F, Ryan D, deJonge L, de la Bretonne J, et al. Contributions of total body fat, abdominal subcutaneous adipose tissue compartments, and visceral adipose tissue to the metabolic complications of obesity. Metabolism. 2001;50(4):425-35. Epub 2001/04/05. https://doi.org/10.1053/ meta.2001.21693. PubMed PMID: 11288037.

195. Demerath EW, Sun SS, Rogers N, Lee M, Reed D, Choh AC, et al. Anatomical patterning of visceral adipose tissue: race, sex, and age variation. Obesity (Silver Spring). 2007;15(12):2984-93. Epub 2008/01/17. https://doi.org/10.1038/oby.2007.356. PubMed PMID: 18198307; PubMed Central PMCID: PMCPMC2883307.

196. Goss AM, Darnell BE, Brown MA, Oster RA, Gower BA. Longitudinal associations of the endocrine environment on fat partitioning in postmenopausal women. Obesity (Silver Spring). 2012;20(5):939-44. Epub 2011/12/17. https://doi.org/10.1038/ oby.2011.362. PubMed PMID: 22173571; PubMed Central PMCID: PMCPMC3663444.

197. Xu H, Barnes GT, Yang Q, Tan G, Yang D, Chou CJ, et al. Chronic inflammation in fat plays a crucial role in the development of obesityrelated insulin resistance. J Clin Invest. 2003;112(12):1821-30. Epub 2003/12/18. https://doi.org/10.1172/JCI19451. PubMed PMID: 14679177; PubMed Central PMCID: PMCPMC296998.

198. Tchkonia T, Thomou T, Zhu Y, Karagiannides I, Pothoulakis $\mathrm{C}$, Jensen MD, et al. Mechanisms and metabolic implications of regional differences among fat depots. Cell Metab. 2013;17(5):644-56. Epub 2013/04/16. https://doi.org/10.1016/j. cmet.2013.03.008. PubMed PMID: 23583168; PubMed Central PMCID: PMCPMC3942783.
199. Pasquarelli-do-Nascimento G, Braz-de-Melo HA, Faria SS, Santos IO, Kobinger GP, Magalhaes KG. Hypercoagulopathy and Adipose Tissue Exacerbated Inflammation May Explain Higher Mortality in COVID-19 Patients With Obesity. Front Endocrinol (Lausanne). 2020;11:530. Epub 2020/08/28. https://doi.org/10. 3389/fendo.2020.00530. PubMed PMID: 32849309; PubMed Central PMCID: PMCPMC7399077.

200. Al Heialy S, Hachim MY, Senok A, Gaudet M, Abou Tayoun A, Hamoudi R, et al. Regulation of Angiotensin- Converting Enzyme 2 in Obesity: Implications for COVID-19. Front Physiol. 2020;11:555039. Epub 2020/10/20. https://doi.org/10.3389/ fphys.2020.555039. PubMed PMID: 33071815; PubMed Central PMCID: PMCPMC7531362.

201. Beyerstedt S, Casaro EB, Rangel EB. COVID-19: angiotensinconverting enzyme 2 (ACE2) expression and tissue susceptibility to SARS-CoV-2 infection. Eur J Clin Microbiol Infect Dis. 2021. Epub 2021/01/04. https://doi.org/10.1007/s10096-020-04138-6. PubMed PMID: 33389262; PubMed Central PMCID: PMCPMC7778857.

202. Hofmann H, Geier M, Marzi A, Krumbiegel M, Peipp M, Fey $\mathrm{GH}$, et al. Susceptibility to SARS coronavirus S protein-driven infection correlates with expression of angiotensin converting enzyme 2 and infection can be blocked by soluble receptor. Biochem Biophys Res Commun. 2004;319(4):1216-21. Epub 2004/06/15. https://doi.org/10.1016/j.bbrc.2004.05.114. PubMed PMID: 15194496; PubMed Central PMCID: PMCPMC7111153.

203. Foldi M, Farkas N, Kiss S, Dembrovszky F, Szakacs Z, Balasko M, et al. Visceral Adiposity Elevates the Risk of Critical Condition in COVID-19: A Systematic Review and Meta-Analysis. Obesity (Silver Spring). 2020. Epub 2020/12/03. https://doi.org/ 10.1002/oby.23096. PubMed PMID: 33263191; PubMed Central PMCID: PMCPMC7753720.

Publisher's Note Springer Nature remains neutral with regard to jurisdictional claims in published maps and institutional affiliations. 